\title{
Habitat and hydrocarbon potential of the Kimmeridgian strata in the central part of the Polish Lowlands
}

\author{
Dariusz WIĘCŁAW ${ }^{1, *}$
}

1 AGH University of Science and Technology, Faculty of Geology, Geophysics and Environmental Protection, al. A. Mickiewicza 30, 30-059 Kraków, Poland

Więcław, D., 2016. Habitat and hydrocarbon potential of the Kimmeridgian strata in the central part of the Polish Lowlands. Geological Quarterly, 60 (1): 192-210, doi: 10.7306/gq.1260

The quantity, genetic type and maturity of organic matter dispersed in the Kimmeridgian strata of the central part of the Polish Lowlands were determined on the basis of results of Rock-Eval, stable carbon isotope composition of bitumen, their fractions and kerogen, biomarker distribution in saturate and aromatic hydrocarbon fraction, elemental composition of kerogen, vitrinite reflectance and maceral composition analyses of 225 rock samples collected from 32 boreholes. The study was conducted separately for Lower and Upper Kimmeridgian rocks in the Szczecin-Miechów and Kościerzyna-Puławy synclinoriums and Mid-Polish Anticlinorium. The best source rocks with TOC up to 6.8 wt.\%, were found in the vicinity of Gostynin in the Mid-Polish Anticlinorium. Generally, the Upper Kimmeridgian strata are fair and good potential source-rocks whereas the Lower Kimmeridgian strata have much lower hydrocarbon potential. Gas-prone, terrigenous Type-III kerogen predominates in the Lower Kimmeridgian strata. The contribution of oil-prone, marine Type-Il kerogen increases in the Upper Kimmeridgian rocks. In the whole profile, only low-sulphur kerogen was recorded, although the situation, when high-sulphur Type-IIS kerogen was mixed with re-worked, non-generative Type-IV kerogen supplied to the sedimentary basin with rocks from eroded land, cannot be excluded. Sedimentary conditions of organic material were variable, usually anoxic and suboxic with domination of siliclastic material in mineral matrix. The maturity of the dispersed organic matter refers mostly to the final phase of the microbial process, or to the initial phase of the low-temperature thermogenic process ("oil window"). The most mature rocks, corresponding up to $0.75 \%$ in the vitrinite reflectance scale, were recognized in the deepest buried parts of the basin (axial part of the Mogilno-Łódź Segment of the Szczecin-Miechów Synclinorium). The most prospecting source rocks were recognised in this area.

Key words: Polish Lowlands, Kimmeridgian, source rock, hydrocarbon potential, biomarkers, carbon stable isotopes.

\section{INTRODUCTION}

Kimmeridgian strata are considered as one of the world class source rocks responsible for hydrocarbon generation of large petroleum accumulations in the Norwegian Sea and the North Sea (Espitalié et al., 1991; Justwan and Dahl, 2005; Gautier, 2005). They are rich in organic matter reaching even $>20$ wt. $\%$ of total organic carbon (TOC) with the average value of ca. 5 wt.\% (Cornford, 1994). The preliminary geochemical studies of these strata in the Polish part of the Kimmeridgian basin have revealed that the abundance of organic carbon is high also in this area, i.e. 2-5 wt.\% (e.g., Wilczek and Merta, 1992; Merta, 1994). Those studies were based on TOC measurements and Rock-Eval data (e.g., Burzewski et al., 1990; Wilczek and Merta, 1992; Merta, 1994) and evidenced the presence of oil-prone kerogen in the upper part of the profile with increasing contribution of gas-prone kerogen in the lower

\section{*E-mail: wieclaw@agh.edu.pl}

Received: July 28, 2015; accepted: October 29, 2015; first published online: November 24, 2015 part, and general low maturity within the whole profile. The petroleum generation analysis conducted for the whole Upper Jurassic complex of the Polish Lowlands (Burzewski et al., 1990; Nowicki, 1990; Bachleda-Curuś et al., 1992) using the standard TTI method (Waples, 1980) generally evidenced that these rocks were not mature enough to generate thermogenic (liquid and gaseous) hydrocarbons, perhaps with the exception of local, deep buried areas of the Szczecin-Miechów and Kościerzyna-Puławy synclinoriums (Szczecin, Łódź and Płock troughs according to Narkiewicz and Dadlez, 2008), where such hydrocarbons may be generated. These possibilities can be read out from numerous signs evidencing the presence of oil and gas in the Upper Jurassic formations in the Wartkowice-Koło-Mogilno area (Karnkowski, 1999). However, no petroleum accumulations of commercial value were found in these strata in Poland. Since that time, single geochemical and petrographical data of the Kimmeridgian rocks in individual boreholes have been published (e.g., Grotek, 2012; Klimuszko, 2012). Hydrocarbon potential of the Upper Jurassic rocks in SE Poland was described by Kosakowski et al. (2012). Więcław (2011) has correlated some oils accumulated in Upper Jurassic-Cretaceous traps of the Carpathian Foredeep Basement with Upper Jurassic source rocks in this area. 


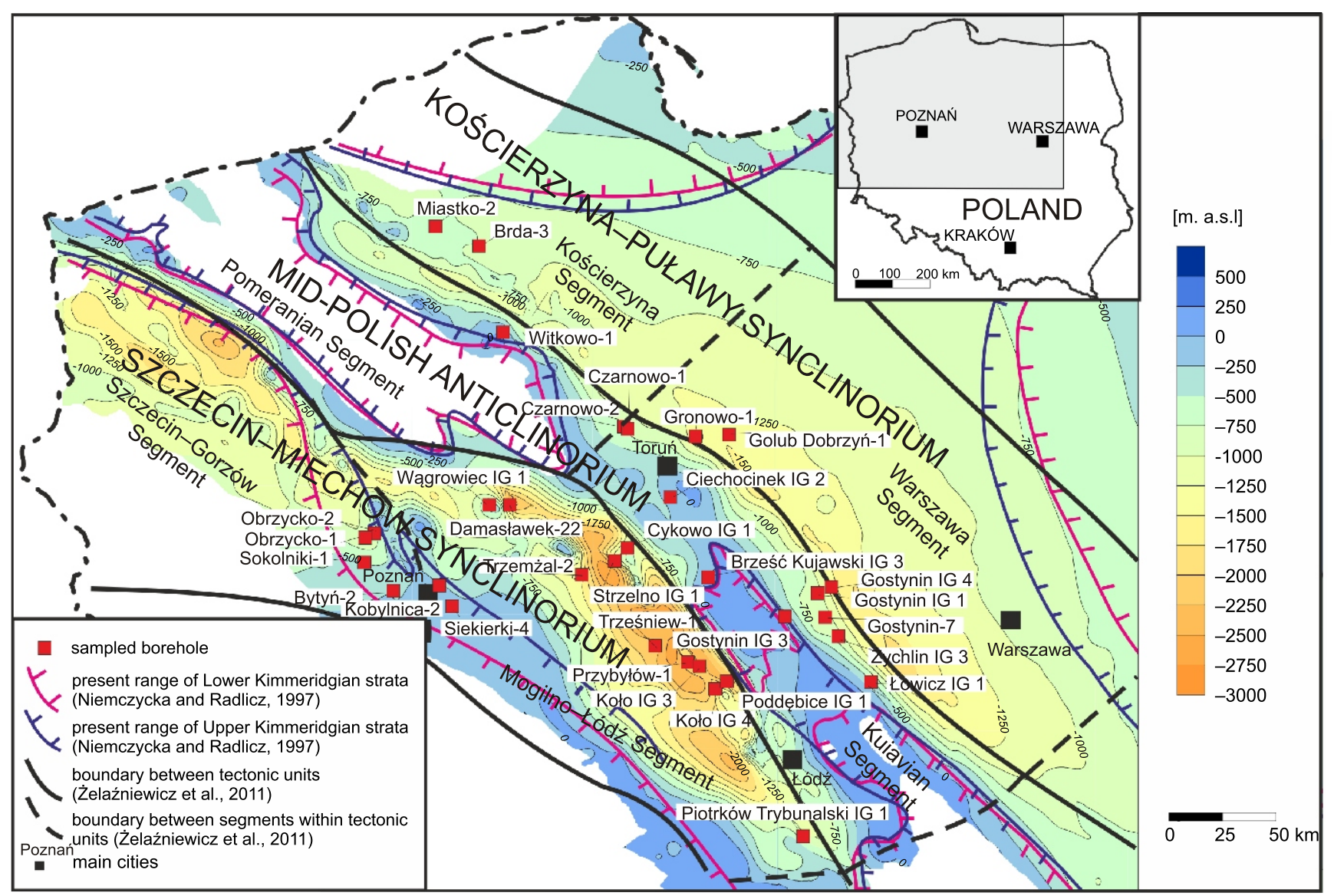

Fig. 1. Location of sampled boreholes on the background of a structural map of the top surface of Upper Jurassic strata in the Polish Lowlands (after Górecki, 2006)

Boundaries between tectonic units and their segments after Żelaźniewicz et al. (2011)

Research conducted on samples of Kimmeridgian rocks in the United Kingdom (Dessort et al., 1997) indicated the presence of highly reactive kerogen Type-IIS characterized by a high sulphur content (> 9 wt.\%; Orr, 1986). No studies of organic sulphur in the Kimmeridgian kerogen have been conducted in Poland yet. By analogy to other parts of the Upper Jurassic basin the Type-IIS kerogen should be also present in its Polish part. High organic sulphur content in kerogen leads to the decomposition of kerogen to oil at lower maturities and so at lower basin temperatures than for typical Type-II kerogen (Lewan, 1998). In this way the kerogen, previously defined as immature, can be considered as capable of generating thermogenic hydrocarbons. By this approach the areas of mature Kimmeridgian strata can be verified.

This study is the first quantitative and qualitative evaluation of source rocks in the Kimmeridgian section of the central part of the Polish Lowlands conducted separately for Lower and Upper Kimmeridgian strata on the basis on a large number of 225 rock samples collected from 32 boreholes (Fig. 1). The quantity of organic matter, its hydrocarbon potential, kerogen type with special attention to high-sulphur kerogen identification and sedimentary conditions, as well as the thermal maturity of the Kimmeridgian sequence were studied with the use of a wide-range of organic geochemistry and petrographic methods. The source rock assessment was based on geochemical criteria proposed by Peters and Cassa (1994) and Hunt (1996).

\section{GEOLOGICAL SETTING}

The study area is located in the central part of the Upper Permian-Mesozoic Polish Basin, being part of the Southern Permian Basin (Geluk, 2007). During inversion of the Polish Basin in its axial part (Krzywiec, 2006) at the end of the Cretaceous and in the Paleogene the main structural units were formed (Karnkowski, 2008; Żelaźniewicz et al., 2011), namely the Szczecin-Miechów Synclinorium, Mid-Polish Anticlinorium and Kościerzyna-Puławy Synclinorium, and monoclines (Fore-Sudetic Monocline and Kraków-Silesian Monocline). This division is generally correlated with the proposal of Narkiewicz and Dadlez (2008), but it differs as regards the definition of boundaries of tectonic units. Each of the synclinoriums and anticlinoriums are divided into segments: Szczecin-Miechów Synclinorium - into the Szczecin-Gorzów, Mogilno-Łódź and Miechów segments, Mid-Polish Anticlinorium - into the Pomeranian, Kuiavian and Szydłowiec segments, and Kościerzyna-Puławy Synclinorium - into the Kościerzyna, Warszawa and Puławy segments (Żelaźniewicz et al., 2011; Fig. 1).

Kimmeridgian lithology of the study area is typical of the Polish Lowlands. The Calcareous-Marly-Coquina (V) Formation (Lower Kimmeridgian) and the Pałuki Formation (VI) (Upper Kimmeridgian) have been identified in the section (Dembowska, 1979; Niemczycka, 1983). The exact Oxfordian/Kimmeridgian boundary in the Submediterranean succes- 
sions of the Polish Lowlands has been described by, e.g., Wierzbowski $(1991,2004)$ and Niemczycka et al. (1997).

The Calcareous-Marly-Coquina (V) Formation is built mainly of compact calcareous marl with oolith, grey marl and compact, light grey limestone with intraclasts. It is represented by marly limestones, micritic, light grey in colour, spotted and mottled. They are enriched with clay material with intraclasts of micrite limestone, and show traces of deposit-feeding organisms and bioturbation. The Pałuki Formation (VI) is represented by dark grey marly mudstones with dolomite, with thin interlayers of light dolomitic marl. The deposits are characterized by a platy habit, sporadically with mica laminae. They contain coquina beds composed of shell detritus. There are numerous bivalves and very scarce ammonites (Niemczycka and Radlicz, 1997).

The Upper Jurassic strata were deposited in a shallow epicontinental sea connected with the Boreal seas and the Tethys Ocean. Contrary to the Oxfordian basin where carbonates were deposited in a very shallow-water environments, during the Kimmeridgian the carbonate shelf began to shrink, the east and west connections opened to the ocean, and the depth of the basin increased by some tens of metres (Niemczycka and Radlicz, 1997). In the deepest parts of the sedimentary basin located in the northern and central parts of the Polish Lowlands, mudstones were deposited. In the southeastern part of the basin, sedimentation of carbonates and anhydrites dominated. The maximum subsidence, usually of 200-250 m, locally slightly exceeding $400 \mathrm{~m}$, occurred in the central part of the basin. Towards the west, north and east, the subsidence significantly decreased (Niemczycka and Brochwicz-Lewiński, 1988). High $\mathrm{CO}_{2}$ content in air (ca. 1000 ppm; Berner, 1990), and therefore an elevated greenhouse effect (Hallam, 1985), did not result in high productivity (ca. $220 \mathrm{~g}^{*} \mathrm{~m}^{-2} * \mathrm{a}$; Weedon et al., 2004). The enrichment of rocks with organic matter is associated with the low content of mineral matrix. The deposition rate was variable, from 50 to $120 \mathrm{~m} / \mathrm{My}$ (Dadlez and Marek, 1997). The present range of the Upper Jurassic strata is strongly limited in relation to the original one. The erosion episodes at the Jurassic/Cretaceous and Cretaceous/Paleogene transitions partly or entirely removed the Upper Jurassic strata from marginal parts of the basin (Niemczycka and Radlicz, 1997).

\section{SAMPLES AND METHODS}

\section{SAMPLES}

Rock samples were taken from drill cores representing Upper and Lower Kimmeridgian strata from the central part of the Polish Lowlands. A total of 225 core samples from 32 boreholes (Fig. 1), weighing about $400 \mathrm{~g}$ each, mainly claystones and mudstones as well as marls and carbonates, were collected and analysed. Table 1 shows the number of samples collected from individual boreholes and stratigraphic levels. From the Lower Kimmeridgian strata, 103 samples were collected: 6 samples from the Kościerzyna-Puławy Synclinorium (4 samples from the Kościerzyna Segment and 2 samples from the Warszawa Segment), 13 - from the Mid-Polish Anticlinorium (all from the Kuiavian Segment) and from the Szczecin-Miechów Synclinorium - 84 samples (12 samples from the Szczecin-Gorzów Segment and 72 - from the Mogilno-Łódź Segment; Table 1). From the Upper Kimmeridgian strata, 122 samples were collected: 18 samples from the Kościerzyna-Puławy Synclinorium (2 from the Kościerzyna Segment and 16 from the Warszawa Segment),
Table 1

Number and stratigraphy of the rock samples collected from the Kimmeridgian strata in individual boreholes

\begin{tabular}{|c|c|c|c|}
\hline Borehole & Borehole code & Lower & Upper \\
\hline \multicolumn{4}{|c|}{ Szczecin-Miechów Synclinorium } \\
\hline \multicolumn{4}{|c|}{ Szczecin-Gorzów Segment } \\
\hline
\end{tabular}

\begin{tabular}{|l|l|l|l|}
\hline Bytyń-2 & By-2 & 2 & \\
\hline Obrzycko-1 & Ob-1 & 6 & \\
\hline Obrzycko-2 & Ob-2 & 2 & \\
\hline Sokolniki-1 & So-1 & 2 & \\
\hline
\end{tabular}

\begin{tabular}{cc} 
Sokolniki-1 & So-1 \\
\hline & Mogilno-Łódź Segment
\end{tabular}

\begin{tabular}{|l|c|c|c|}
\hline Cykowo IG 1 & Cy-1 & & 2 \\
\hline Damasławek-22 & Da-22 & 28 & 5 \\
\hline KobyInica-2 & Kb-2 & 1 & \\
\hline Koło IG 3 & Ko-3 & 7 & 6 \\
\hline Koło IG 4 & Ko-4 & 3 & 4 \\
\hline Piotrków Trybunalski IG 1 & PT-1 & 3 & 2 \\
\hline Poddębice IG 1 & Po-1 & 9 & 5 \\
\hline Przybyłów-1 & Pr-1 & 4 & 6 \\
\hline Siekierki-4 & Si-4 & 3 & \\
\hline Strzelno IG 1 & St-1 & 3 & 2 \\
\hline Trzemżal-2 & Tr-2 & & 1 \\
\hline Trześniew-1 & Tw-1 & 4 & \\
\hline Wągrowiec IG 1 & Wa-1 & 7 & 9 \\
\hline \multicolumn{2}{|l|}{ Mid-Polish Anticlinorium }
\end{tabular}

\begin{tabular}{|c|c|c|}
\hline \multicolumn{3}{|c|}{ Mid-Polish Anticlinorium } \\
\hline \multicolumn{3}{|c|}{ Pomeranian Segment } \\
\hline Witkowo-1 Kuiavian Segment \\
\hline \multicolumn{4}{|c|}{ Wi-1 } & 5 \\
\hline
\end{tabular}

\begin{tabular}{|c|c|c|c|}
\hline Brześć Kujawski IG 3 & BK-3 & 3 & \\
\hline Ciechocinek IG 2 & $\mathrm{Ci}-2$ & 1 & 7 \\
\hline Czarnowo-1 & $\mathrm{Cz}-1$ & & 15 \\
\hline Czarnowo-2 & $\mathrm{Cz}-2$ & & 12 \\
\hline Gostynin IG 1/1A & Go-1 & 3 & 5 \\
\hline Gostynin IG 3 & Go-3 & 2 & 10 \\
\hline Gostynin-7 & Go-7 & & 3 \\
\hline Łowicz IG 1 & Lo-1 & 3 & 2 \\
\hline Żychlin IG 3 & $2 y-3$ & 1 & 3 \\
\hline \multicolumn{4}{|c|}{ Kościerzyna-Puławy Synclinorium } \\
\hline \multicolumn{4}{|c|}{ Kościerzyna Segment } \\
\hline Brda-3 & $\mathrm{Br}-3$ & & 2 \\
\hline Miastko-2 & Mi-2 & 4 & \\
\hline \multicolumn{4}{|c|}{ Warszawa Segment } \\
\hline Golub Dobrzyń-1 & GD-1 & & 3 \\
\hline Gostynin IG 4 & Go-4 & 2 & 5 \\
\hline Gronowo-1 & Gr-1 & & 8 \\
\hline TOTAL & & 103 & 122 \\
\hline
\end{tabular}

59 samples - from the Mid-Polish Anticlinorium (5 from the Pomeranian Segment and 54 from the Kuiavian segment) and from the Szczecin-Miechów Synclinorium - 45 samples from the Mogilno-Łódź Segment (Table 1).

\section{METHODS}

The rock samples were water-washed from contamination and crushed to fraction $<20 \mathrm{~mm}$ and $\mathrm{ca}$. $150 \mathrm{~g}$ was powdered to fraction $<0.2 \mathrm{~mm}$ for geochemical analyses. The screening pyrolysis was conducted for all samples using a Rock-Eval II ap- 
paratus equipped with the TOC module. Aliquots of selected 13 samples were extracted with dichloromethane:methanol (93:7 $\mathrm{v} / \mathrm{v}$ ) in the Soxhlet apparatus. The extraction was conducted until traces of bitumen were present in the solution in the extractor (determined by UV luminescence). The asphaltene fraction of all received bitumen was precipitated with $n$-hexane. The remaining maltenes were separated into saturated hydrocarbon aromatic hydrocarbon and resin fractions by column chromatography, using alumina/silica gel $(2: 1 \mathrm{v} / \mathrm{v})$ columns $(0.8 \times$ $25 \mathrm{~cm}$ ). The fractions were eluted with petroleum ether (boiling range $\left.40-65^{\circ} \mathrm{C}\right)$, toluene, and toluene:methanol $(1: 1 \mathrm{v} / \mathrm{v})$, respectively. Stable carbon isotope analyses of kerogen, bitumen and bitumen fractions were performed for 13 samples with the Finnigan Delta Plus mass spectrometer. The stable carbon isotope data is presented in the $\delta$-notation relative to the VPDB standard (Coplen, 2011), at the estimated analytical accuracy of $\pm 0.2 \%$. Before the measurements, rock samples subjected to stable carbon isotope analysis of kerogen were purified from carbonates by treatment of hot $10 \% \mathrm{HCl}$. Isolation of 8 kerogen samples for elemental analyses was achieved according to the procedure described by, e.g., Więcław et al. (2011). The isolated saturated hydrocarbon fractions from 11 bitumen samples were diluted in isooctane spiked by $5 \beta$-cholane and analysed with the Agilent $7890 \mathrm{~A}$ gas chromatograph coupled with a 5975C mass selective detector (MSD) for biomarker determination according to the procedure presented by Wieckaw et al. (2012). In the selected ion mode (SIM) the dwell time of the operated MSD was set to 30 milliseconds for each ion. The aromatic hydrocarbon fractions of 11 bitumen samples were diluted in toluene spiked by ortho-terphenyl as the standard and analysed by the GC-MS using the same equipment as for the saturate hydrocarbons fraction. The $\mathrm{GC}$ oven was programmed from 40 to $300^{\circ} \mathrm{C}$ at the rate of $3^{\circ} \mathrm{C} \mathrm{min}{ }^{-1}$. The MS was operated with a cycle time of $1 \mathrm{sec}$ in the mass range from 40 to 600 Daltons. The selected ions were monitored: $\mathrm{m} / \mathrm{z}=71$ (alkanes), $\mathrm{m} / \mathrm{z}=191$ (hopanes (terpanes)) and $\mathrm{m} / \mathrm{z}=217$ (steranes) in saturate hydrocarbon fraction, and $\mathrm{m} / \mathrm{z}=178$ (Phenanthrene), $\mathrm{m} / \mathrm{z}=192$ (methylphenanthrenes), $\mathrm{m} / \mathrm{z}=184$ (Dibenzothiophene), $\mathrm{m} / \mathrm{z}=198$ (methyldibenzothiophenes) and $\mathrm{m} / \mathrm{z}=231$ (triaromatic steroids) in aromatic hydrocarbon fraction. Tentative peaks identifications were conducted based on elution time and confirmed with mass spectra (Philp, 1985). The quantitative assessment of individual hydrocarbons was performed comparing their peak area with the peak area of the standard ( $5 \beta$-cholane or ortho-terphenyl). All geochemical analyses were performed at the AGH University of Science and Technology in Kraków. Measurements of mean random reflectance of vitrinite $\left(R_{r}\right)$ were carried out with a Zeiss-Opton microphotometer at a wave-length of $546 \mathrm{~nm}$, in oil. Sample preparation and point counts were carried out in accordance with the ICCP procedure. Petrographic studies of organic matter included quantitative analyses of vitrinite, liptinite, and inertinite maceral groups performed for 8 samples using an Axioplan-Opton microscope at the Polish Geological Institute National Research Institute in Warsaw.

\section{RESULTS AND DISCUSSION}

The Lower and Upper Kimmeridgian strata of the Polish Basin had been deposited in one sedimentary basin, but later tectonic events, leading to the formation of the Szczecin-Miechów Synclinorium, Mid-Polish Anticlinorium and Kościerzyna-Puławy Synclinorium, and the resulting differences in burial depth, have changed the hydrocarbon potential of organic mat- ter in the individual units. Therefore, organic matter is described separately for each tectonic unit.

\section{SZCZECIN-MIECHÓW SYNCLINORIUM}

From the Szczecin-Miechów Synclinorium, 129 samples from 17 boreholes were collected (Table 1 and Fig. 1). Eighty-four samples came from Lower Kimmeridgian strata of 15 boreholes; 45 samples originated from Upper Kimmeridgian rocks of 10 boreholes (Table 1). Most of the samples were collected from boreholes located in the Mogilno-Łódź Segment. Only 12 samples came from Lower Kimmeridgian strata from 4 boreholes drilled in the Szczecin-Gorzów Segment (Table 1) close to the boundary with the Mogilno-Łódź Segment (Fig. 1). The TOC content varies in the Lower Kimmeridgian strata from 0.13 to $2.1 \mathrm{wt} . \%$, with the median of 0.39 , and in the Upper Kimmeridgian - from 0.19 to 4.7 wt.\% (median 1.78 wt.\%;Table 2). Samples with low TOC values predominate, but high organic carbon contents, $>2$ wt. $\%$, were recorded in many sections (Fig. 2A). The highest TOC values were recorded in the Upper Kimmeridgian strata of the Koło IG 4 borehole. The residual hydrocarbon content $\left(S_{2}\right)$ and total hydrocarbon content $\left(S_{1}+S_{2}\right)$, similarly to the TOC values, are usually low in the Lower Kimmeridgian strata and range from 0.07 to $5.2 \mathrm{mg} \mathrm{HC} / \mathrm{g}$ rock and from 0.12 to $5.3 \mathrm{mg} \mathrm{HC} / \mathrm{g}$ rock (medians 0.51 and 0.63 $\mathrm{mg} \mathrm{HC} / \mathrm{g}$ rock), respectively (Table 2 and Fig. 2A); in the Upper Kimmeridgian, they are much higher and vary from 0.14 to 18.9 and from 0.19 to $19.8 \mathrm{mg} \mathrm{HC} / \mathrm{g}$ rock, respectively, with the median values of 4.1 and $4.4 \mathrm{mg} \mathrm{HC} / \mathrm{g}$ rock, accordingly (Table 2 and Fig. 2A). It indicates that the Lower Kimmeridgian strata are generally poor and the Upper Kimmeridgian strata are fair (locally even good) sources for the generation of hydrocarbons. The highest medians of TOC value in individual boreholes are noted in the Upper Kimmeridgian strata in the Koło-Przybyłów area (Fig. 1).

The correlation between the hydrogen index $\mathrm{HI}$ and the temperature $T_{\max }$ (Fig. $3 \mathrm{~A}$ ) proves that different types of kerogen are present in the Kimmeridgian strata of this tectonic unit. In the Lower Kimmeridgian strata, gas-prone Type-III kerogen predominates. Locally, it is enriched in Type-II kerogen; in the Upper Kimmeridgian rocks, the proportion of oil-prone Type-Il kerogen is much greater (Table 2 and Fig. 3A). The highest $H I$ values were noted in the Piotrków Trybunalski IG 1, Damasławek-22, Koło IG 3, Koło IG 4, Poddębice IG 1 and Przybyłów-1 boreholes (Fig. 3A). The mineral matrix effect resulting in the lowering of $H I$ values for samples poor in organic-carbon is weak; the low $H I$ values are noted for samples rich and poorer in organic material both in the Lower and Upper Kimmeridgian (Fig. 4A). Lowering of TOC content is accompanied by elevated OI values, which suggests a partial oxidation of low-content organic matter rocks (Fig. 4A'). The results of petrographic analyses conducted on four Upper Kimmeridgian samples (Table 3 and Fig. 5) show the predominance of oil-prone kerogen. The highest proportion of liptinite macerals (ca. 95\%) was recorded in sample PT-1/1195.3 (it has the highest $H I$ value $-458 \mathrm{mg} \mathrm{HC} / \mathrm{g}$ TOC; Fig. $3 \mathrm{~A}$ ), while the lowest one (ca. 40\%) was observed in sample Pr-1/1992.5 (Fig. 5). Stable carbon isotope analyses indicate the narrow range of $\delta^{13} \mathrm{C}$ values of kerogen and asphaltenes, and a considerable difference between $\delta^{13} \mathrm{C}$ values of bitumen and fractions of samples collected from the Lower and Upper Kimmeridgian strata (Table 4 and Fig. 6A). The second mentioned group is highly enriched in ${ }^{12} \mathrm{C}$ isotope. The sample richest in organic matter, Ko-4/1976, has the most negative $\delta^{13} \mathrm{C}$ value of saturates, and it falls in the area of terrigenous organic matter on the Sofer's (1984) dia- 
Geochemical characteristics and hydrocarbon potential of the Kimmeridgian strata in the cental part of the Polish Lowlands based on Rock-Eval data

\begin{tabular}{|c|c|c|c|c|c|c|}
\hline \multirow{2}{*}{ Index } & \multicolumn{2}{|c|}{ Szczecin-Miechów Synclinorium } & \multicolumn{2}{|c|}{ Mid-Polish Anticlinorium } & \multicolumn{2}{|c|}{ Kościerzyna-Puławy Synclinorium } \\
\hline & Lower & Upper & Lower & Upper & Lower & Upper \\
\hline TOC [wt.\%] & $\frac{0.13 \text { to } 2.1}{0.39} \quad \frac{(84)}{(15)}$ & $\frac{0.19 \text { to } 4.7}{1.78} \quad \frac{(45)}{(10)}$ & $\frac{0.18 \text { to } 6.8}{0.94} \frac{(13)}{(6)}$ & $\frac{0.25 \text { to } 6.6}{2.6} \frac{(59)}{(9)}$ & $\frac{0.22 \text { to } 3.2}{0.40} \quad \frac{(6)}{(2)}$ & $\frac{0.38 \text { to } 5.6}{2.4} \frac{(18)}{(4)}$ \\
\hline$T_{\max }\left[{ }^{\circ} \mathrm{C}\right]$ & $\frac{421 \text { to } 439}{429} \frac{(82)}{(15)}$ & $\frac{420 \text { to } 449}{433} \frac{(41)}{(10)}$ & $\frac{418 \text { to } 432}{421} \frac{(11)}{(6)}$ & $\frac{419 \text { to } 435}{428} \frac{(59)}{(9)}$ & $\frac{412 \text { to } 428}{422} \frac{(6)}{(2)}$ & $\frac{412 \text { to } 432}{425} \frac{(18)}{(4)}$ \\
\hline $\begin{array}{c}\mathrm{S}_{2} \\
\text { [mg HC/g rock] }\end{array}$ & $\frac{0.07 \text { to } 5.2}{0.51} \quad \frac{(84)}{(15)}$ & $\frac{0.14 \text { to } 18.9}{4.1} \quad \frac{(45)}{(10)}$ & $\frac{0.05 \text { to } 24.8}{0.94} \frac{(13)}{(6)}$ & $\frac{0.26 \text { to } 25.6}{4.1} \frac{(59)}{(9)}$ & $\frac{0.19 \text { to } 11.6}{0.29} \frac{(6)}{(2)}$ & $\frac{0.16 \text { to } 26.2}{4.2} \frac{(18)}{(4)}$ \\
\hline $\begin{array}{c}S_{1}+S_{2} \\
{[\mathrm{mg} \mathrm{HC} / \mathrm{g} \text { rock }]}\end{array}$ & $\frac{0.12 \text { to } 5.3}{0.63}$ & $\frac{0.19 \text { to } 19.8}{4.4} \quad \frac{(45)}{(10)}$ & $\frac{0.09 \text { to } 25.4}{1.05} \frac{(13)}{(6)}$ & $\frac{0.34 \text { to } 26.1}{4.2} \frac{(59)}{(9)}$ & $\frac{0.26 \text { to } 11.9}{0.38} \frac{(6)}{(2)}$ & $\frac{0.26 \text { to } 26.7}{4.3} \frac{(18)}{(4)}$ \\
\hline$P I$ & $\frac{0.06 \text { to } 0.42}{0.17} \frac{(84)}{(15)}$ & $\frac{0.02 \text { to } 0.26}{0.06} \frac{(45)}{(10)}$ & $\frac{0.02 \text { to } 0.44}{0.10} \frac{(13)}{(6)}$ & $\frac{0.01 \text { to } 0.24}{0.04} \frac{(59)}{(9)}$ & $\frac{0.03 \text { to } 0.28}{0.24} \frac{(6)}{(2)}$ & $\frac{0.01 \text { to } 0.38}{0.04} \frac{(18)}{(4)}$ \\
\hline $\begin{array}{c}H I \\
{[\mathrm{mg} \mathrm{HC} / \mathrm{g} \text { TOC] }}\end{array}$ & $\frac{54 \text { to } 408}{139} \frac{(84)}{(15)}$ & $\frac{32 \text { to } 458}{189} \frac{(45)}{(10)}$ & $\frac{25 \text { to } 363}{94} \frac{(13)}{(6)}$ & $\frac{58 \text { to } 441}{141} \frac{(59)}{(9)}$ & $\frac{66 \text { to } 358}{94} \frac{(6)}{(2)}$ & $\frac{35 \text { to } 508}{149} \frac{(18)}{(4)}$ \\
\hline Kerogen type & III (III/II) & $\| / / I I I I I,, I I)$ & III (III/II) & $\|/\| \|(I I I, \|)$ & III (III/II) & $\| / / I I(I I I, \|)$ \\
\hline Maturity & $\begin{array}{l}\text { immature/ } \\
\text { low-mature }\end{array}$ & immature/mature & $\begin{array}{l}\text { immature/ } \\
\text { low-mature }\end{array}$ & $\begin{array}{l}\text { immature/ } \\
\text { low-mature }\end{array}$ & immature & $\begin{array}{l}\text { immature/ } \\
\text { low-mature }\end{array}$ \\
\hline $\begin{array}{l}\text { Hydrocarbon } \\
\text { potential }\end{array}$ & poor & fair/good & fair & good & poor & good \\
\hline
\end{tabular}

TOC - total organic carbon; $T_{\max }$ - temperature of maximum of $S_{2}$ peak; $S_{2}-$ residual petroleum potential; $S_{1}-$ oil and gas yield [mg HC/g rock]; $\mathrm{Pl}$ - production index; $\mathrm{HI}$ - hydrogen index; range of geochemical parameters is given as numerator; median values in denominator, in parentheses: number of samples from boreholes (numerator) and number of sampled boreholes (denominator); kerogen type in brackets secondary occurrence

gram (Fig. 7). This picture is similar to that of the lower part of the Menilite Formation in the Polish Carpathians (Curtis et al., 2004; Kotarba et al., 2007), where such light isotopic signature of saturates was recorded for samples with high $\mathrm{HI}$ values (dominance of marine Type-II kerogen). On the basis of biomarker analyses, Köster et al. (1998) explained the existence of the isotopically light kerogen combined with isotopically light biomarkers in terms of the activity of methanotrophic bacteria. Such carbon stable isotope composition may also be indicative of high algal content, usually typical of Lower Paleozoic sediments (Riding, 2001). Very high value of the $\mathrm{HI} / \mathrm{O} /$ ratio, ca. $25 \mathrm{mg} \mathrm{HC} / \mathrm{mg} \mathrm{CO}$ (Fig. 8), of the sample supports the presence of algal-rich kerogen (Peters and Cassa, 1994). On the other hand, kerogen elemental composition shows the presence of mixed Type-III/II kerogen (Table 5 and Fig. 9). Taking into consideration the maceral composition of this sample (dominance of liptinite and inertinite macerals) one can conclude that re-worked (inert) organic matter dispersed in rocks eroded from land was added to algal material (Type-II or Type-I kerogen) derived from organisms living in the sea. The same situation is visible in other samples, also from other tectonic units (Fig. 5). The low values of the $S / C$ atomic ratios in kerogen, below 0.04 (Table 5), reveal the presence of low- and mid-sulphur (slow- and mid-generative) kerogen (Orr, 1986) in the Upper Kimmeridgian strata, but the positive correlation of $\mathrm{S} / \mathrm{C}$ and $\mathrm{H} / \mathrm{C}$ atomic ratios (Fig. 10) may indicate that variable proportions of low-sulphur kerogen (most probably Type-IV) were added to the sediment containing high-sulphur kerogen (Type-IIS). Distribution of biomarkers (Fig. 11) and values of calculated ratios (Pristane/n- $\mathrm{C}_{17}$ and Phytane/n- $\mathrm{C}_{18}$; Table 6 and Fig. 12) as well as the homological contribution to regular steranes (Table 7 and Fig. 13) support previous results and indicate that the analysed bitumen was generated from oil-prone Type-Il kerogen of planktonic origin. The presence of algal Type-I kerogen in sample Ko-3/2146.5 cannot be excluded (Fig. 12). Organic matter was deposited usually in normal marine conditions $(1<\mathrm{Pr} / \mathrm{Ph}<3$, Table 6; Didyk et al., 1978) and locally in anoxic conditions $(\mathrm{Pr} / \mathrm{Ph}<1)$. Low values of the gammacerane index ( $\mathrm{G}$; Table 7 ) indicate the absence of hypersaline sedimentation environment (Sininghe Damste et al., 1995). The distribution of regular steranes (Fig. 13) as well as values of the ratios calculated based on the distribution of steranes, diasteranes and hopanes (Table 7) indicate the same type of organic matter in all the Kimmeridgian samples, deposited mostly in marine shales or marls (Figs. 14 and 15). Values of Pristane/Phytane and Dibenzothiophene/Phenanthrene ratios in bitumen extracted from some samples suggest generation from organic matter deposited in lacustrine conditions (Fig. 14). However, for lacustrine organic matter the value of $\mathrm{C}_{26} / \mathrm{C}_{25}$ of triterpanes ratio is above unity (e.g., Zumberge, 1987). For all analysed samples this ratio is below unity (Table 7 and Fig. 15) evidencing the dominance of marine kerogen.

Thermal maturity of the Kimmeridgian strata in the Szczecin-Miechów Synclinorium was determined based on Rock-Eval data (Table 2), measurements of vitrinite reflectance (Table 3), and biomarker (Table 7) and aromatic hydrocarbons distribution (Table 8). The results of the kerogen elemental composition analysis ( $\mathrm{H} / \mathrm{C}$ and $\mathrm{O} / \mathrm{C}$ values) were also used indirectly for this purpose (Table 5). The $T_{\max }$ values, in criteria of Espitalié et al. (1985), indicate the maturity of the investigated 

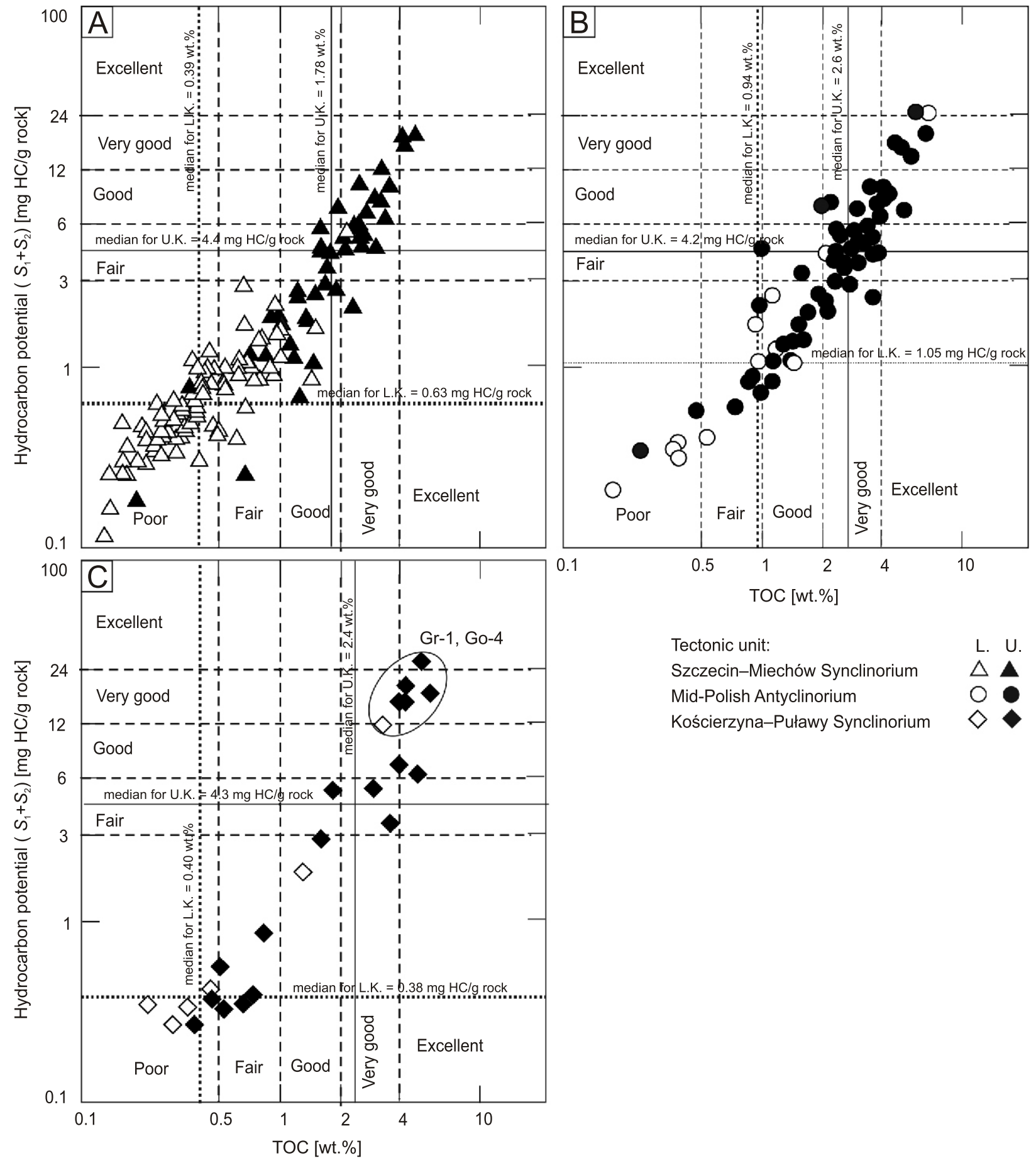

$\begin{array}{ll}\text { Tectonic unit: } & \text { L. U. } \\ \text { Szczecin-Miechów Synclinorium } & \triangle 1 \\ \text { Mid-Polish Antyclinorium } & \diamond \\ \text { Kościerzyna-Puławy Synclinorium } & \diamond\end{array}$

Fig. 2. Petroleum source quality diagram for organic matter in (A) Szczecin-Miechów Synclinorium, (B) Mid-Polish Anticlinorium and (C) Kościerzyna-Puławy Synclinorium according to criteria of Peters and Cassa (1994)

L. - lower; U. - upper; K. - Kimmeridgian; for borehole codes see Table 1; solid lines represent median values of TOC and $S_{1}+S_{2}$ for Upper Kimmeridgian strata and dotted lines represent median values of TOC and $S_{1}+S_{2}$ for Lower Kimmeridgian strata in individual tectonic units 

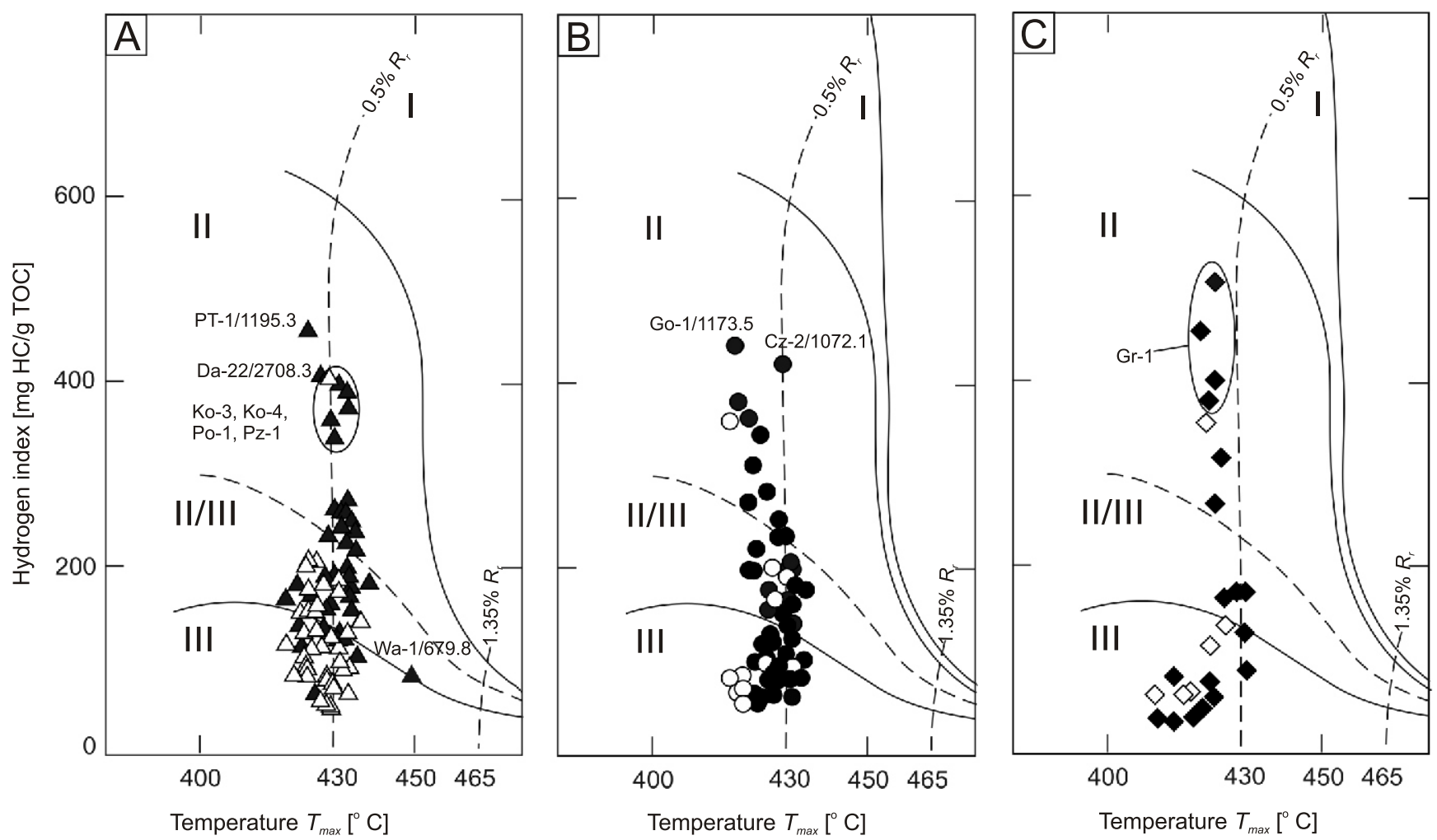

Fig. 3. Rock-Eval hydrogen index versus temperature $T_{\max }$ for identification of genetic type and maturity of organic matter in (A) Szczecin-Miechów Synclinorium, (B) Mid-Polish Anticlinorium and (C) Kościerzyna-Puławy Synclinorium

Genetic paths of individual kerogen types (I-III) and maturity fields after Espitalié et al. (1985); other explanations as in Figure 2
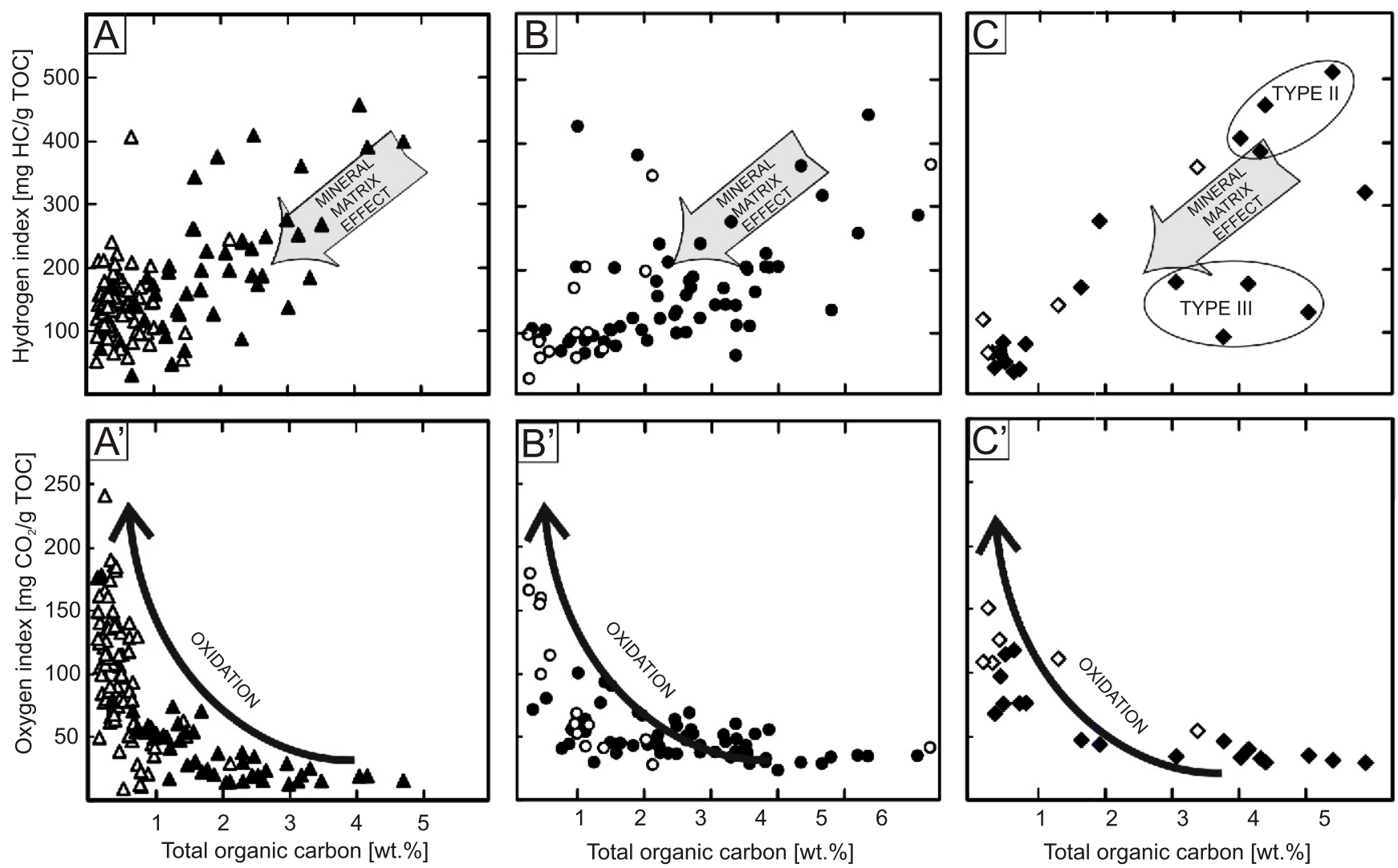

Fig. 4. Rock-Eval (A, B and C) hydrogen index and (A', B' and C') oxygen index versus total organic carbon content for (A and A') Szczecin-Miechów Synclinorium, (B and B') Mid-Polish Anticlinorium and (C and C')

Kościerzyna-Puławy Synclinorium 
Vitrinite reflectance and petrographic composition of Kimmeridgian organic matter

\begin{tabular}{|c|c|c|c|c|c|c|c|c|c|c|c|c|}
\hline \multirow{2}{*}{$\begin{array}{l}\text { Borehole } \\
\text { code }\end{array}$} & \multirow{2}{*}{$\begin{array}{c}\text { Depth } \\
\text { [m] }\end{array}$} & \multirow{2}{*}{ Age } & \multirow{2}{*}{$\begin{array}{c}R_{r} \\
{[\%]}\end{array}$} & \multirow{2}{*}{$\begin{array}{l}\text { stdv } \\
{[\%]}\end{array}$} & \multirow{2}{*}{$n$} & \multirow{2}{*}{$\begin{array}{l}\text { Vitrinite } \\
{[\%]}\end{array}$} & \multirow{2}{*}{$\begin{array}{l}\text { Liptinite }_{[\%]}^{*} \\
\text { [\%] }\end{array}$} & \multirow{2}{*}{$\begin{array}{c}\text { Inertinite + } \\
\text { Inertodetrinite } \\
{[\%]}\end{array}$} & \multirow{2}{*}{$\begin{array}{l}\sum \text { organic } \\
\text { matter [\%] }\end{array}$} & Vitrinite & Liptinite & Inertinite \\
\hline & & & & & & & & & & \multicolumn{3}{|c|}{ Sum $=100 \%$} \\
\hline \multicolumn{13}{|c|}{ Szczecin-Miechów Synclinorium } \\
\hline Ko-4 & 1976.0 & U. K. & 0.63 & 0.051 & 75 & 1.0 & 3.8 & 2.2 & 7.0 & 14 & 55 & 31 \\
\hline Po-1 & 2402.5 & U. K. & 0.62 & 0.066 & 75 & 1.6 & 2.7 & 0.7 & 5.0 & 32 & 54 & 14 \\
\hline Pr-1 & 1992.5 & U. K. & 0.77 & 0.046 & 55 & 4.0 & 7.0 & 7.0 & 18.0 & 22 & 39 & 39 \\
\hline PT-1 & 1195.3 & U. K. & 0.61 & 0.056 & 36 & 0.7 & 20.0 & 0.5 & 21.2 & 3 & 95 & 2 \\
\hline \multicolumn{13}{|c|}{ Mid-Polish Anticlinorium } \\
\hline $\mathrm{Ci}-2$ & 561.7 & U. K. & 0.56 & 0.053 & 70 & 0.6 & 2.1 & 1.1 & 3.8 & 16 & 55 & 29 \\
\hline Cy-1 & 1089.3 & U. K. & 0.52 & 0.048 & 53 & 0.1 & 2.0 & 0.9 & 3.0 & 3 & 67 & 30 \\
\hline Go-7 & 1177.2 & U. K. & 0.63 & 0.071 & 65 & 0.9 & 7.0 & 5.4 & 13.3 & 7 & 52 & 41 \\
\hline \multicolumn{13}{|c|}{ Kościerzyna-Puławy Synclinorium } \\
\hline $\mathrm{Gr}-1$ & 1651.4 & U. K. & 0.53 & 0.046 & 37 & 0.7 & 15.0 & 2.4 & 18.1 & 4 & 83 & 13 \\
\hline
\end{tabular}

$R_{r}$ - random virtinite reflectance; stdv - standard deviation; $n$ - number of measurements; * - algae, alginite, bitumine, bituminous bodies; U. K. - Upper Kimmeridgian

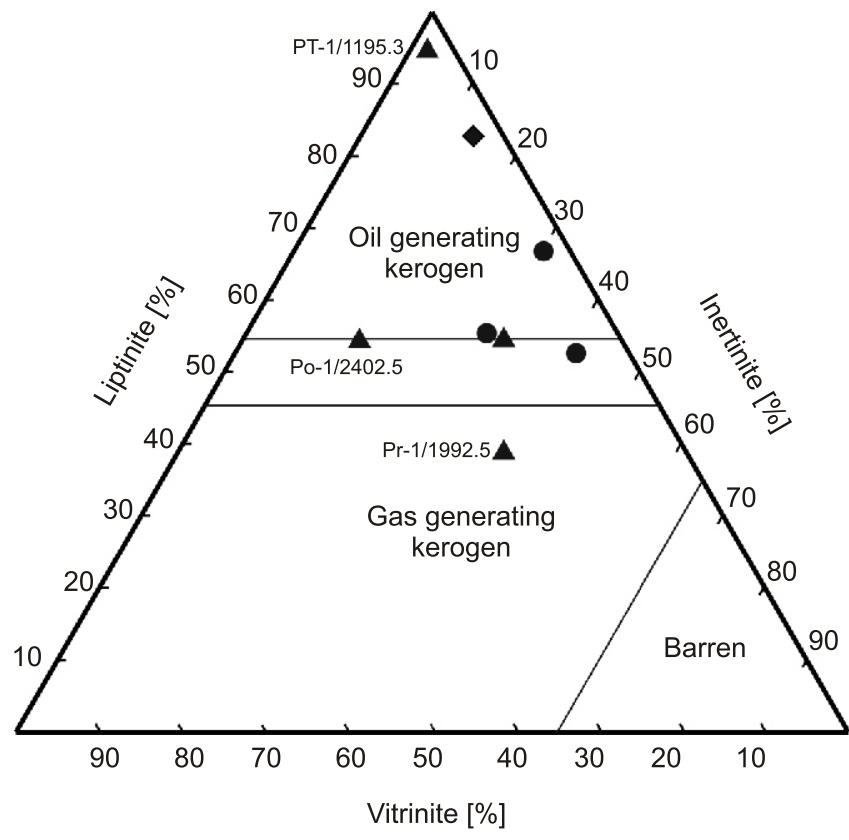

Fig. 5. Tertiary diagram of maceral composition of organic matter

Genetic boundaries after Leenheer (1984); explanations as in Figure 2

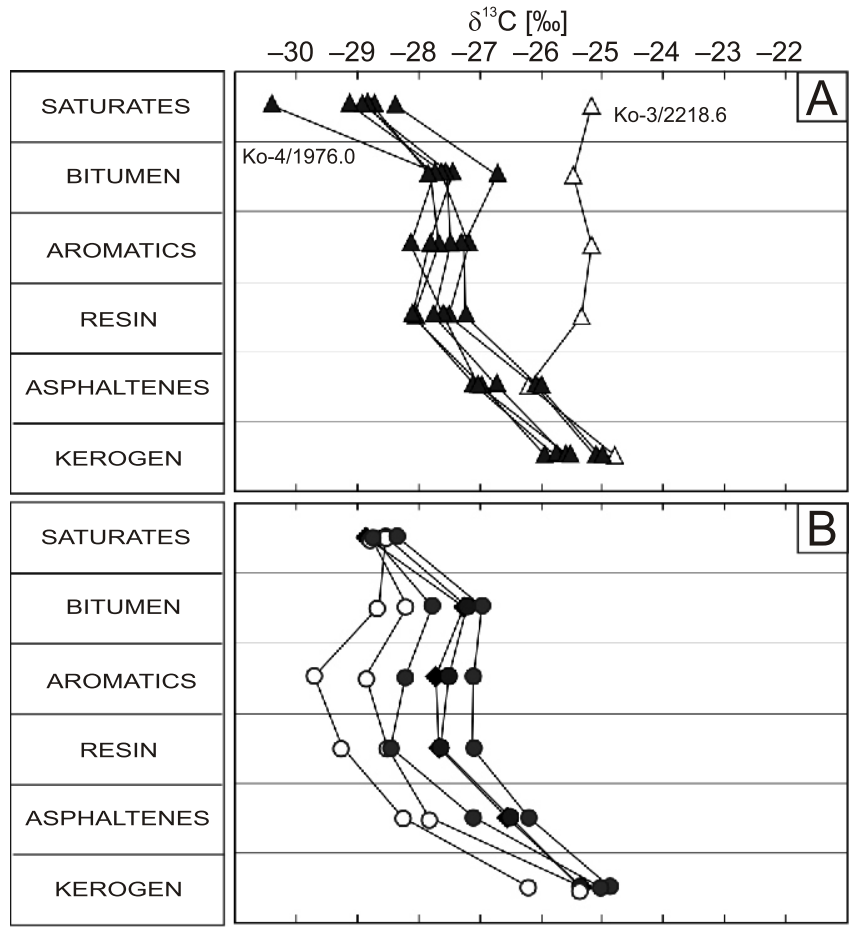

Fig. 6. Stable carbon isotope composition of bitumen, their individual fractions and kerogen in (A) Szczecin-Miechów Synclinorium and (B) Mid-Polish Anticlinorium and Kościerzyna-Puławy Synclinorium

Explanations as in Figure 2 

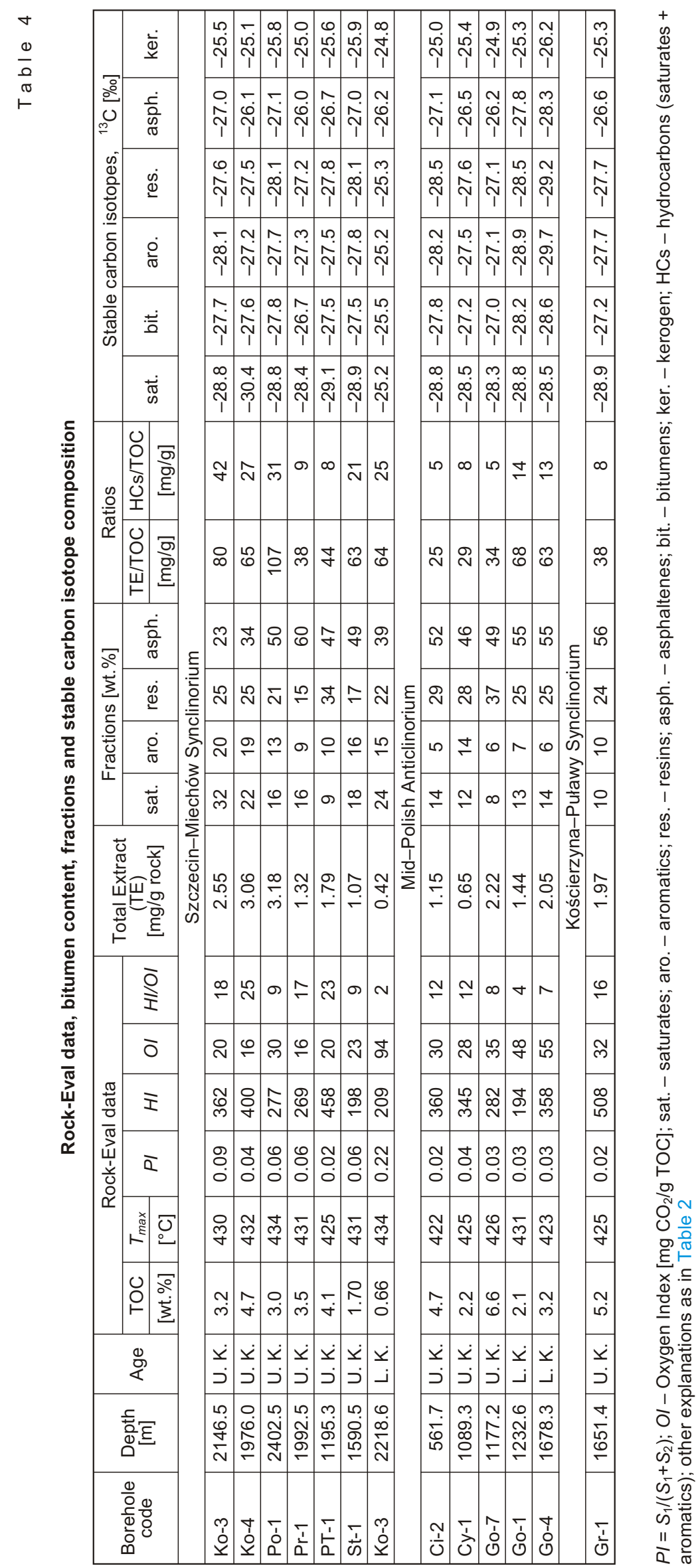


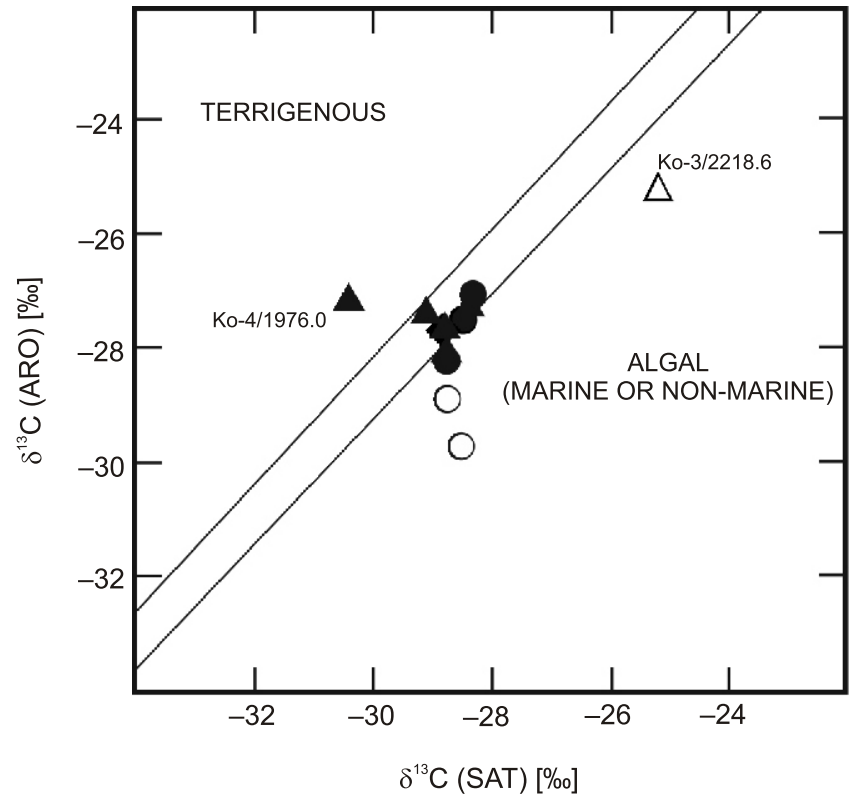

Fig. 7. Stable carbon isotope composition of saturates versus aromatics in bitumen

Genetic fields after Sofer (1984); explanations as in Figure 2

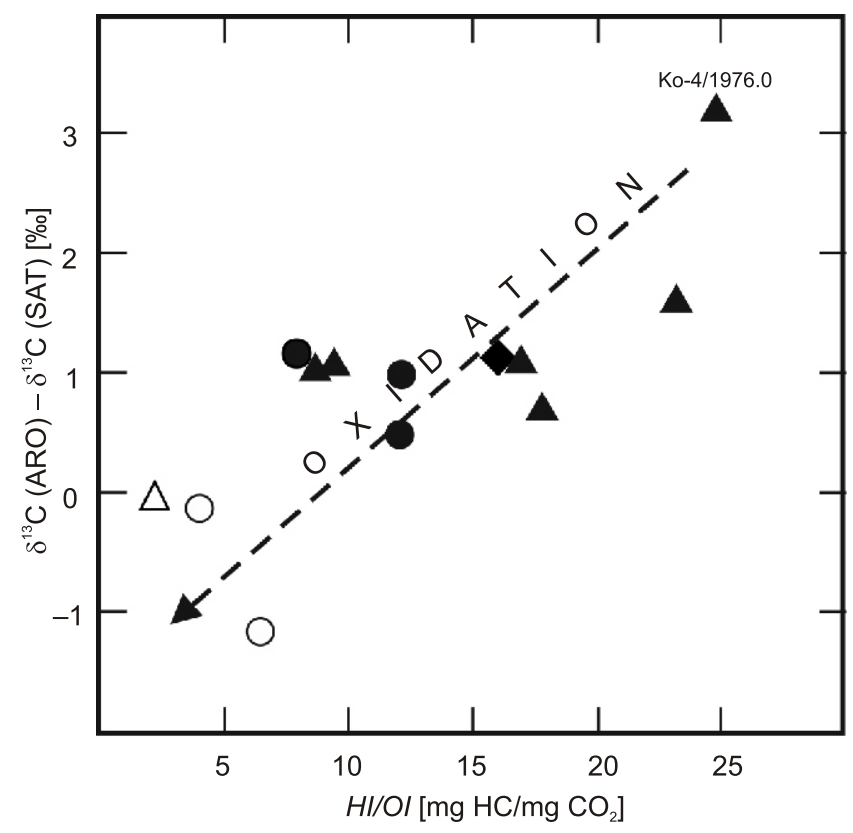

Fig. 8. Difference of stable carbon isotope composition between aromatics and saturates versus hydrogen index/oxygen index ratio

Explanations as in Figure 2

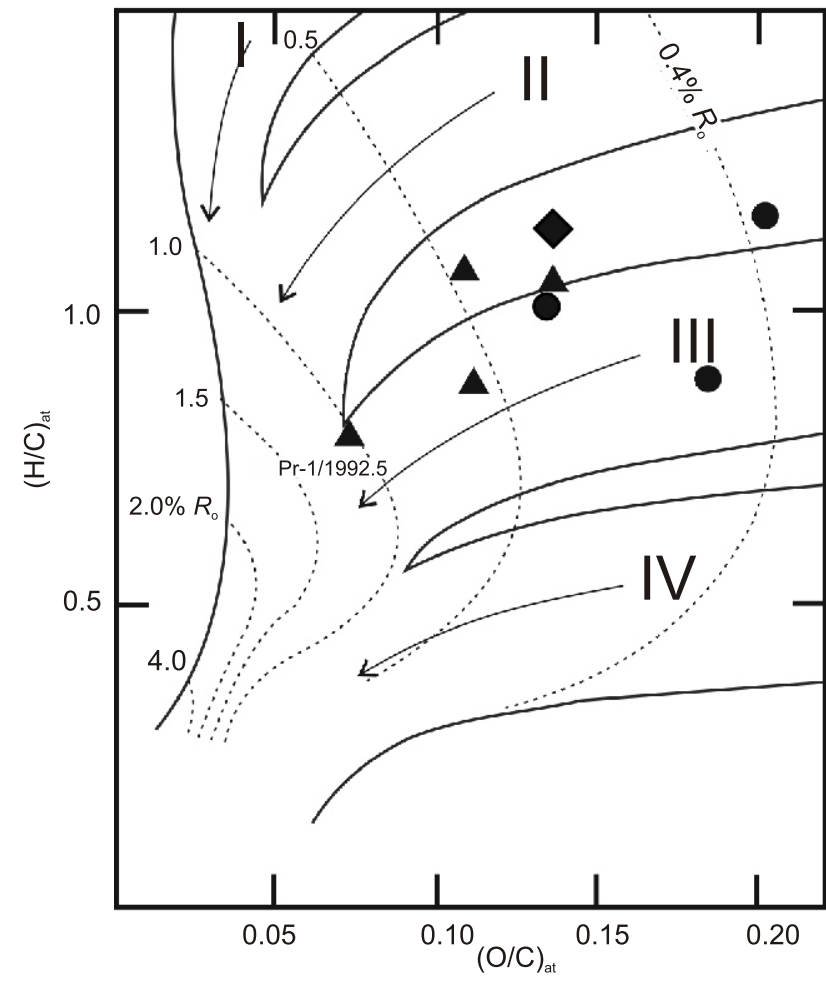

Fig. 9. $(\mathrm{H} / \mathrm{C})_{\text {atomic }}$ versus $(\mathrm{O} / \mathrm{C})_{\text {atomic }}$ for organic matter from Upper Kimmeridgian strata

Fields represent natural maturity paths for individual kerogen types (I-IV) after Hunt (1996); explanations as in Figure 2

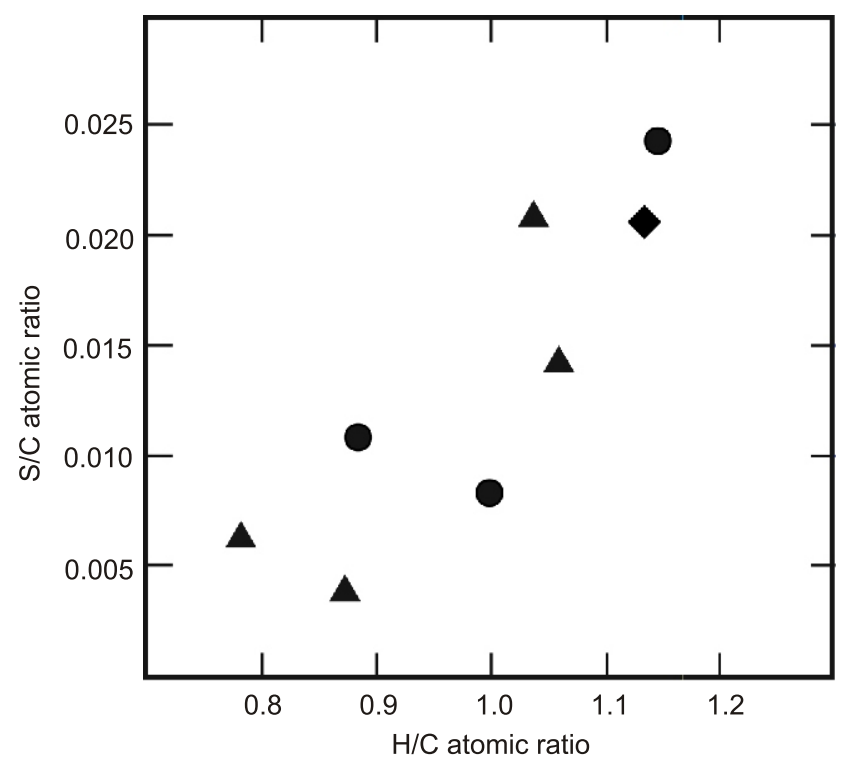

Fig. 10. $(\mathrm{S} / \mathrm{C})_{\text {atomic }}$ versus $(\mathrm{H} / \mathrm{C})_{\text {atomic }}$ for organic matter from Upper Kimmeridgian strata

Explanations as in Figure 2 
Elemental composition of kerogen

\begin{tabular}{|c|c|c|c|c|c|c|c|c|c|c|c|}
\hline \multirow{2}{*}{$\begin{array}{l}\text { Borehole } \\
\text { code }\end{array}$} & \multirow{2}{*}{$\begin{array}{c}\text { Depth } \\
{[\mathrm{m}]}\end{array}$} & \multirow{2}{*}{ Age } & \multicolumn{5}{|c|}{ Elemental composition [daf, wt.\%] } & \multicolumn{4}{|c|}{ Atomic ratio } \\
\hline & & & C & $\mathrm{H}$ & $\mathrm{O}$ & $\mathrm{N}$ & $S$ & $\mathrm{H} / \mathrm{C}$ & $\mathrm{O} / \mathrm{C}$ & $\mathrm{N} / \mathrm{C}$ & $\mathrm{S} / \mathrm{C}$ \\
\hline \multicolumn{12}{|c|}{ Szczecin-Miechów Synclinorium } \\
\hline Ko-4 & 1976,0 & U. K. & 74.3 & 6.4 & 13.5 & 1.6 & 4.2 & 1.04 & 0.14 & 0.018 & 0.021 \\
\hline Po-1 & 2402.5 & U. K. & 79.7 & 5.8 & 12.0 & 1.7 & 0.8 & 0.87 & 0.11 & 0.018 & 0.004 \\
\hline Pr-1 & 1992.5 & U. K. & 82.8 & 5.4 & 8.2 & 2.2 & 1.4 & 0.78 & 0.07 & 0.023 & 0.006 \\
\hline PT-1 & 1195.3 & U. K. & 76.8 & 6.8 & 11.2 & 2.3 & 2.9 & 1.06 & 0.11 & 0.025 & 0.014 \\
\hline \multicolumn{12}{|c|}{ Mid-Polish Anticlinorium } \\
\hline $\mathrm{Ci}-2$ & 561.7 & U. K. & 68.8 & 6.6 & 18.8 & 1.4 & 4.5 & 1.15 & 0.20 & 0.017 & 0.024 \\
\hline Cy-1 & 1089.3 & U. K. & 76.2 & 6.3 & 13.7 & 2.1 & 1.7 & 1.00 & 0.13 & 0.023 & 0.008 \\
\hline Go-7 & 1177.2 & U. K. & 72.8 & 5.4 & 18.1 & 1.6 & 2.1 & 0.88 & 0.19 & 0.019 & 0.011 \\
\hline \multicolumn{12}{|c|}{ Kościerzyna-Puławy Synclinorium } \\
\hline Gr-1 & 1651.4 & U. K. & 73.2 & 6.9 & 13.3 & 2.5 & 4.1 & 1.13 & 0.14 & 0.030 & 0.021 \\
\hline
\end{tabular}

daf - dry, ash-free basis; other explanations as in Figure 2

Table 6

Indices calculated based on $\boldsymbol{n}$-alkane and isoprenoid distribution of bitumen

\begin{tabular}{|c|c|c|c|c|c|c|c|c|c|c|}
\hline $\begin{array}{c}\text { Borehole } \\
\text { code }\end{array}$ & $\begin{array}{c}\text { Depth } \\
{[\mathrm{m}]}\end{array}$ & Age & $\mathrm{CPI}_{\text {(Total) }}$ & $\mathrm{CPI}_{(17-23)}$ & $\mathrm{CPI}_{(25-31)}$ & $\mathrm{Pr} / n-\mathrm{C}_{17}$ & $\mathrm{Ph} / n-\mathrm{C}_{18}$ & $\mathrm{Pr} / \mathrm{Ph}$ & $\mathrm{C}_{19-22 / \mathrm{C} 25-28}$ & $\mathrm{C}_{\max }$ \\
\hline \multicolumn{11}{|c|}{ Szczecin-Miechów Synclinorium } \\
\hline Ko-3 & 2146.5 & U. K. & 1.11 & 1.11 & 1.09 & 1.00 & 2.04 & 0.72 & 2.49 & 17 \\
\hline Ko-4 & 1976.0 & U. K. & 1.09 & 1.01 & 1.25 & 1.27 & 0.75 & 1.54 & 1.52 & 20 \\
\hline Po-1 & 2402.5 & U. K. & 1.10 & 1.03 & 1.27 & 1.20 & 0.60 & 2.05 & 1.78 & 20 \\
\hline Pr-1 & 1992.5 & U. K. & 1.04 & 1.00 & 1.06 & 1.18 & 0.54 & 1.62 & 1.48 & 20 \\
\hline PT-1 & 1195.3 & U. K. & 1.39 & 1.18 & 1.78 & 2.61 & 2.61 & 1.41 & 1.23 & 17 \\
\hline St-1 & 1590.5 & U. K. & 1.07 & 1.00 & 1.26 & 1.12 & 0.59 & 1.36 & 2.07 & 19 \\
\hline Ko-3 & 2218.6 & L. K. & 0.99 & 0.95 & 1.04 & 0.32 & 0.30 & 0.79 & 1.48 & 20 \\
\hline \multicolumn{11}{|c|}{ Mid-Polish Anticlinorium } \\
\hline $\mathrm{Ci}-2$ & 561.7 & U. K. & n.c. & n.c. & 2.27 & n.c. & 1.26 & n.c. & 0.69 & 27 \\
\hline Cy-1 & 1089.3 & U. K. & n.c. & n.c. & 1.29 & n.c. & n.c. & n.c. & 1.56 & 21 \\
\hline Go-7 & 1177.2 & U. K. & n.c. & n.c. & 2.02 & n.c. & n.c. & n.c. & 1.00 & 29 \\
\hline \multicolumn{11}{|c|}{ Kościerzyna-Puławy Synclinorium } \\
\hline $\mathrm{Gr}-1$ & 1651.4 & U. K. & 1.76 & 1.29 & 2.61 & 1.18 & 1.93 & 0.75 & 1.15 & 17 \\
\hline
\end{tabular}

$\mathrm{CPI}_{(\text {Total })}=\left[\left(\mathrm{C}_{17}+\mathrm{C}_{19}+\ldots+\mathrm{C}_{27}+\mathrm{C}_{29}\right)+\left(\mathrm{C}_{19}+\mathrm{C}_{21}+\ldots+\mathrm{C}_{29}+\mathrm{C}_{31}\right)\right] /\left[2^{*}\left(\mathrm{C}_{18}+\mathrm{C}_{20}+\ldots+\mathrm{C}_{28}+\mathrm{C}_{30}\right)\right] ; \mathrm{CPI}_{(17-23)}=\left[\left(\mathrm{C}_{17}+\mathrm{C}_{19}+\right.\right.$ $\left.\left.\mathrm{C}_{21}\right)+\left(\mathrm{C}_{19}+\mathrm{C}_{21}+\mathrm{C}_{23}\right)\right] /\left[2^{*}\left(\mathrm{C}_{18}+\mathrm{C}_{20}+\mathrm{C}_{22}\right)\right] ; \mathrm{CPI}_{(25-31)}=\left[\left(\mathrm{C}_{25}+\mathrm{C}_{27}+\mathrm{C}_{29}\right)+\left(\mathrm{C}_{27}+\mathrm{C}_{29}+\mathrm{C}_{31}\right)\right] /\left[2^{*}\left(\mathrm{C}_{26}+\mathrm{C}_{28}+\mathrm{C}_{30}\right)\right] ; \mathrm{Pr}-$ Pristane; $\mathrm{Ph}-\mathrm{Phytane}$; n.c. - not calculated due to low intensity of hydrocarbons; other explanations as in Figure 2 


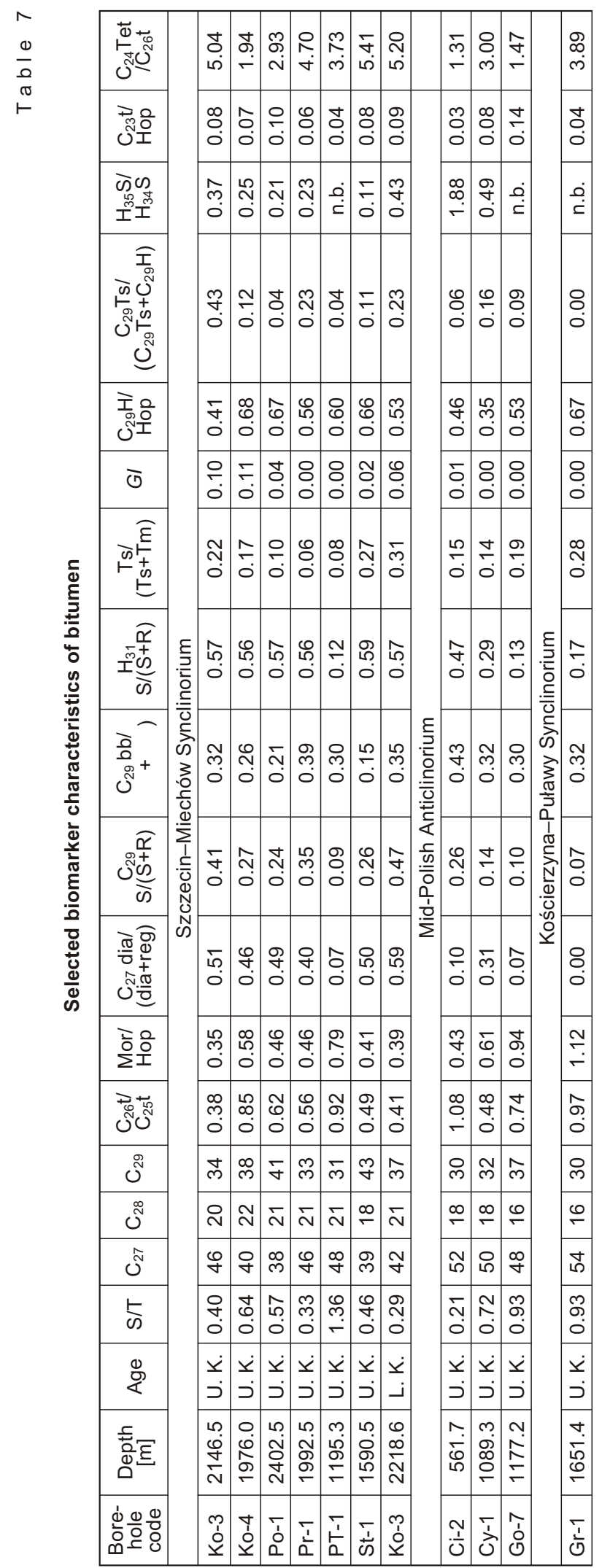

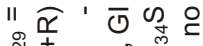

ن̛ं

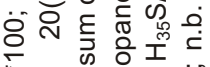

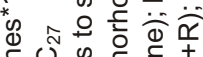

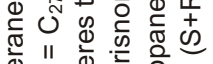

के क्षे

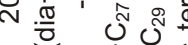

8.

जิ

+0 는

نَّ

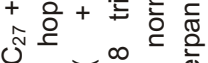

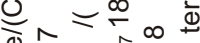

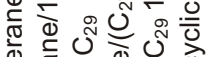

के

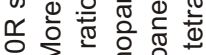

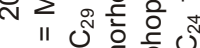

8 응 of क्

Uิ

"1

Ũ

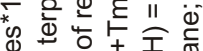

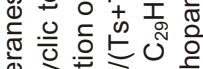

ब

年

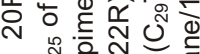

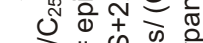

웡

ज्ञ

+ +

Oٓ Oٓ क N

$+40$

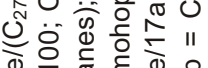

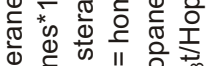

के 흔

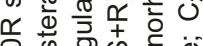

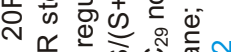

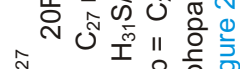

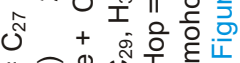

"1 î. is $\infty$ i बن

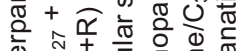

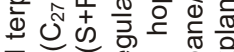

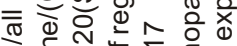
क⿺

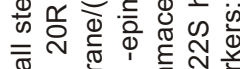

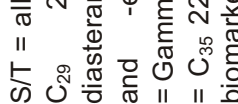



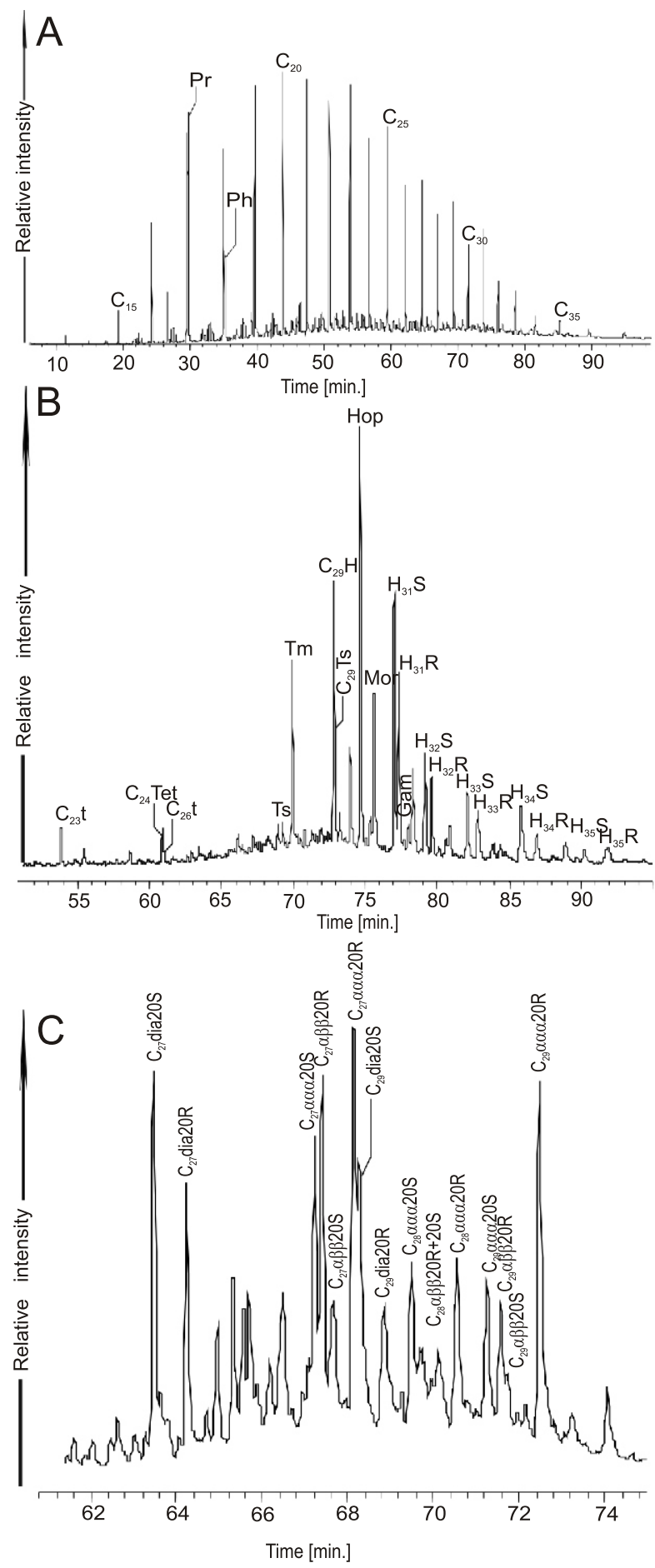

Fig. 11. Example of $(A)$ alkane $(\mathrm{m} / \mathrm{z}=71)$, $(B)$ hopane $(\mathrm{m} / \mathrm{z}=$ 191) and $(C)$ sterane $(\mathrm{m} / \mathrm{z}=217)$ distribution in saturate hydrocarbons fraction (sample Po-1/2402.5 m, Upper Kimmeridgian, Szczecin-Miechów Synclinorium)

For explanation of abbreviations and symbols see Tables 6 (alkanes) and 7 (hopanes and steranes)

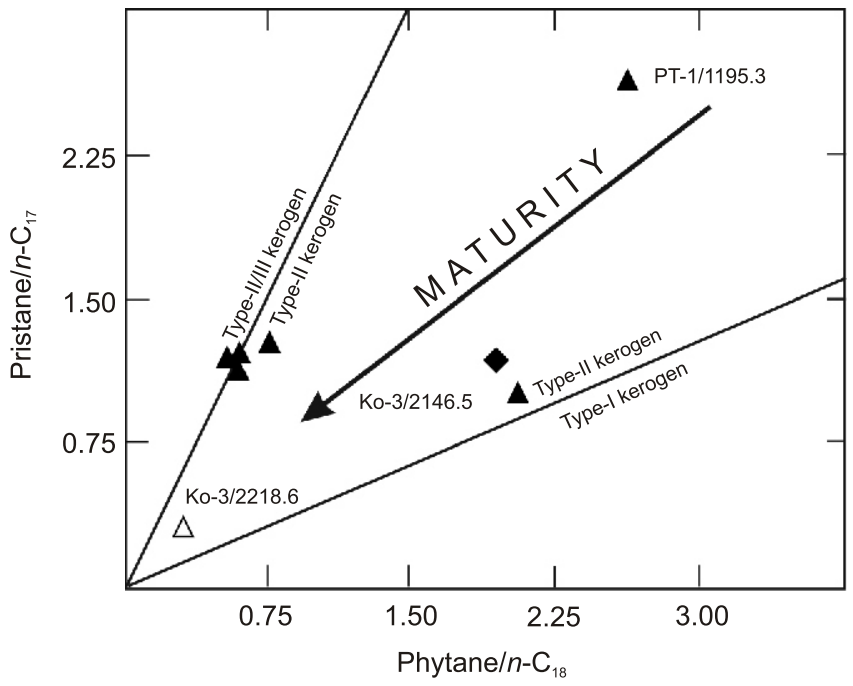

Fig. 12. Genetic characterization of bitumen in terms of pristane $/ n-\mathrm{C}_{17}$ and phytane $/ n-\mathrm{C}_{18}$ according to the categories of Obermajer et al. (1999)

Explanations as in Figure 2

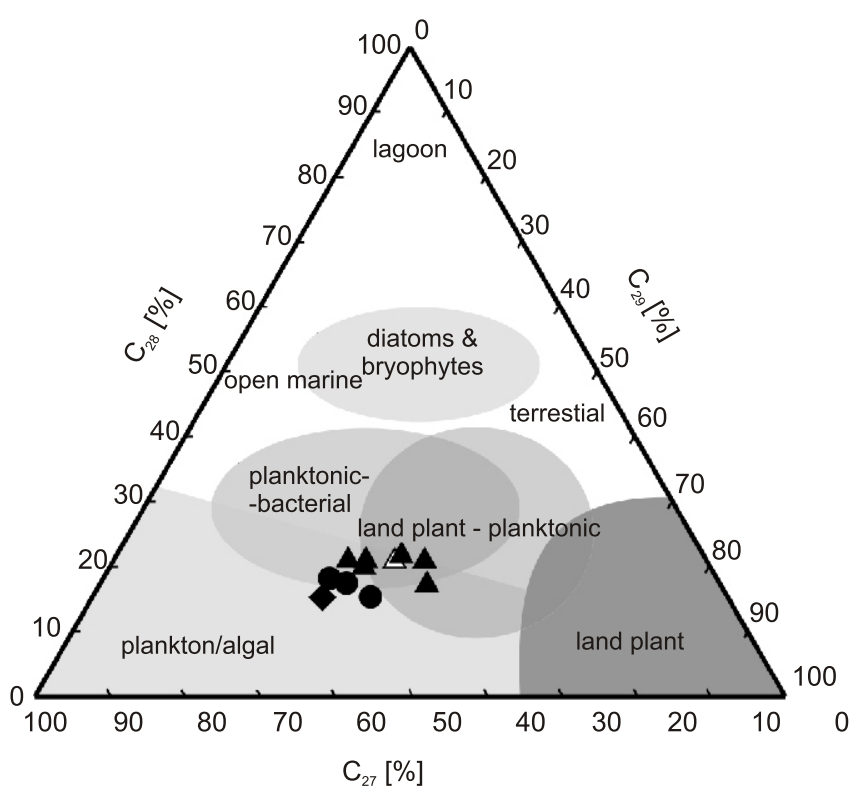

Fig. 13. Tertiary diagram of $20 \mathrm{R}$ regular sterane distribution

Genetic fields modified after Peters et al. (2005); explanations as in Figure 2 


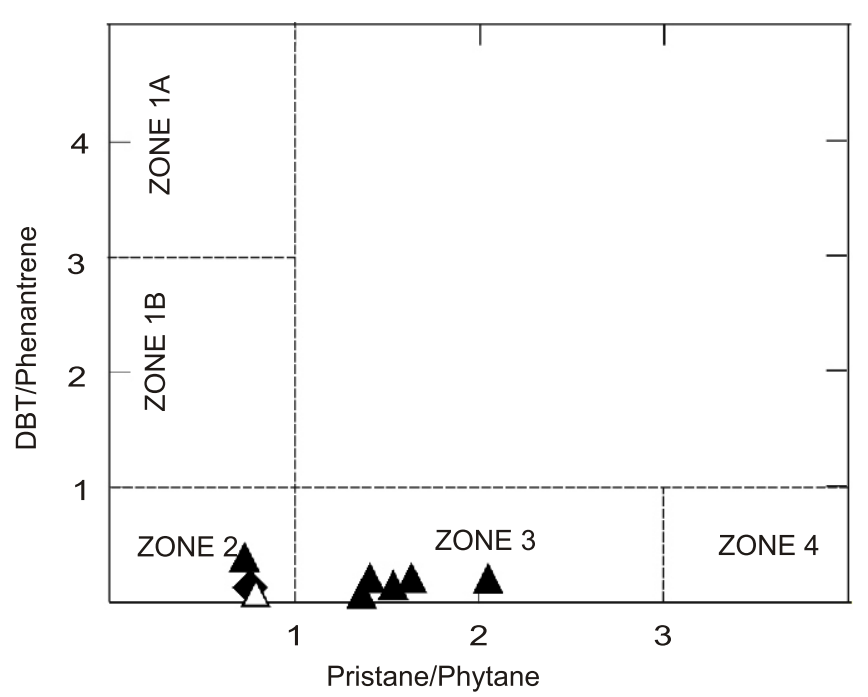

Fig. 14. A cross-plot of the dibenzotiophene/phenantrene ratio versus the pristane/phytane ratio for bitumen

Classification of source kerogen sedimentation conditions after Hughes et al. (1995). Zone 1A - marine carbonate; Zone 1B - marine carbonate or marine marl or lacustrine sulphate-rich; Zone 2 lacustrine sulphate - poor or carbonate organic-poor; Zone 3 - marine shale and other lacustrine; Zone 4 - fluvial/deltaic; explanations as in Figure 2

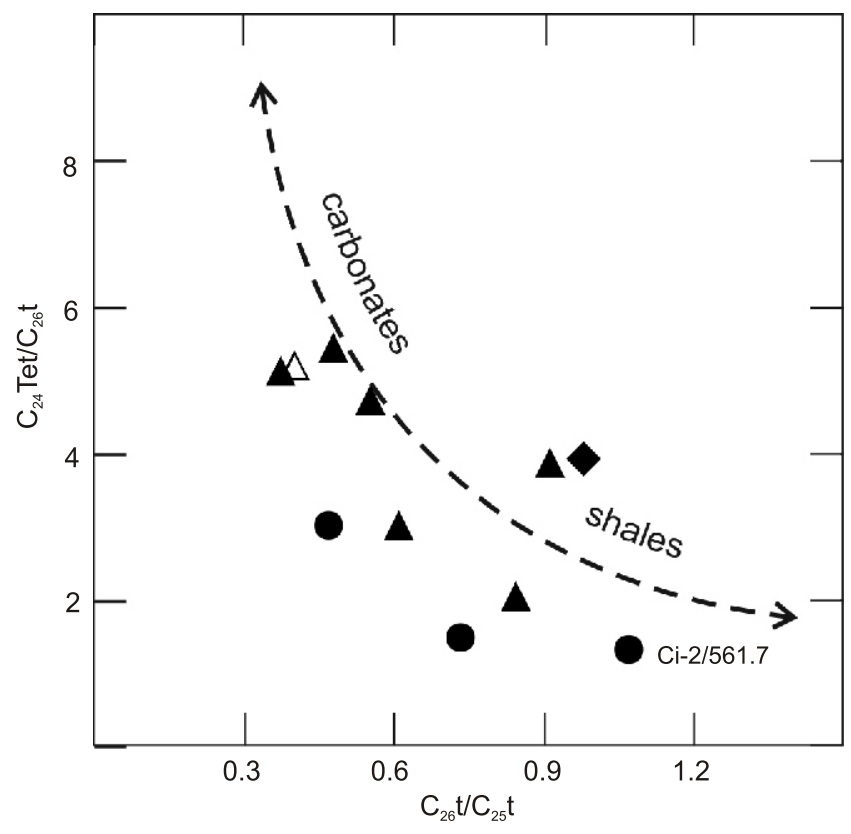

Fig. 15. $C_{24}$ tetracyclic terpane/ $C_{26}$ tricyclic terpane (S+R) ratio versus $\mathrm{C}_{26} / \mathrm{C}_{25}$ of tricyclic terpanes ratio for bitumen

Criteria after Peters et al. (2005); explanations as in Figure 2

strata from the stage of microbial process to the middle phase of "oil window" (from 420 to $449^{\circ} \mathrm{C}$; Table 2 and Fig. 3A). Most of the investigated strata are at the final stage of microbial process or are low-mature. The highest $T_{\max }$ value was recorded in the Wagrowiec IG 1 borehole (Fig. 3A). This maturity increase is often associated with salt tectonics (e.g., near Damasławek salt diapir, Magri et al., 2008). The maturity indices calculated
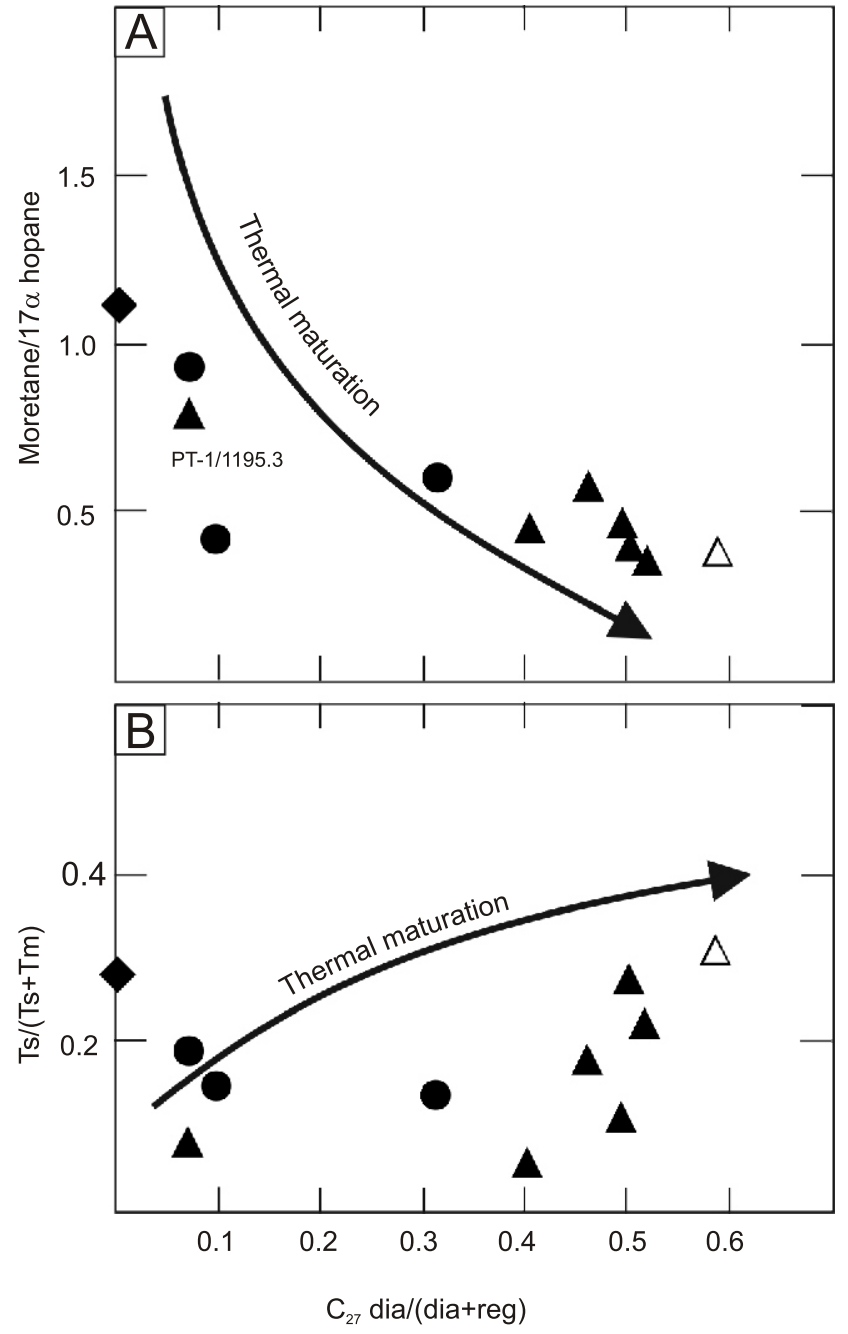

Fig. 16. (A) Moretane/ $17 \alpha$ hopane ratio and (B) $T s /(T s+T m)$ ratio versus $C_{27} \beta \alpha 20(S+R)$ diasterane/( $C_{27} \beta \alpha 20(S+R)$ diasterane $+\Sigma C_{27}$ regular steranes) ratio for bitumen

Criteria after Peters et al. (2005); explanations as in Figure 2

based on the distribution of biomarkers, methylphenantrenes, methyldibenzotiophenes and triaromatic steroids (Tables 7 and 8; Figs. 16 and 17), elemental composition of kerogen (Fig. 9), as well as vitrinite reflectance of the discussed organic matter (Table 3 ) generally correlate with $T_{\max }$ values. The most mature levels were recorded in the Przybyłów-1 borehole (Table 3, Figs. 9 and 17), and generally the highest ones were noted in the most deeply buried part of the synclinorium, in the Damasławek-Koło area (Fig. 1). These data are in agreement with previous studies (e.g., Burzewski et al., 1990; Nowicki, 1990; Bachleda-Curuś and Semyrka, 1990).

\section{MID-POLISH ANTICLINORIUM}

From the Mid-Polish Anticlinorium, 72 samples were collected from 10 boreholes (Table 1 and Fig. 1). They came mostly from the Kuiavian Segment (67 samples from 9 boreholes) and only 5 samples were taken from Upper Kimmeridgian strata of the Pomeranian Segment, from the Witkowo-1 borehole. From Lower Kimmeridgian strata, 13 
Selected indices calculated based on aromatic hydrocarbons distribution of bitumen

\begin{tabular}{|c|c|c|c|c|c|c|c|c|c|c|c|c|}
\hline $\begin{array}{c}\text { Borehole } \\
\text { code }\end{array}$ & $\begin{array}{c}\text { Depth } \\
{[\mathrm{m}]}\end{array}$ & Age & MPI1 & $\begin{array}{c}\mathrm{R}_{\text {cal(MPI1) }} \\
{[\%]}\end{array}$ & MDR & $\begin{array}{c}\mathrm{R}_{\mathrm{cal}(\mathrm{MDR})} \\
{[\%]}\end{array}$ & $\begin{array}{l}\text { DBT/ } \\
\text { Phen }\end{array}$ & $\begin{array}{c}\mathrm{TA}(\mathrm{I}) / \\
\mathrm{TA}(\mathrm{I}+\mathrm{II})\end{array}$ & $\begin{array}{c}\text { TA 20/ } \\
(20+27) \\
\end{array}$ & $\begin{array}{c}\text { TA 21/ } \\
(21+28) \\
\end{array}$ & $\begin{array}{l}\mathrm{TA} \mathrm{C}_{281} \\
\mathrm{C}_{26} 20 \mathrm{~S}\end{array}$ & $\begin{array}{l}\mathrm{TA} \mathrm{C}_{28 /} \\
\mathrm{C}_{27} 20 \mathrm{R}\end{array}$ \\
\hline \multicolumn{13}{|c|}{ Szczecin-Miechów Synclinorium } \\
\hline Ko-3 & 2146.5 & U. K. & 0.00 & 0.37 & 0.30 & 0.48 & 0.34 & I.i. & I.i. & I.i. & I.i. & I.i. \\
\hline Ko-4 & 1976.0 & U. K. & 0.41 & 0.61 & 0.53 & 0.54 & 0.12 & 0.04 & 0.06 & 0.02 & 1.5 & 1.17 \\
\hline PT-1 & 1195.3 & U. K. & 0.28 & 0.54 & 0.39 & 0.50 & 0.13 & I.i. & I.i. & I.i. & I.i. & I.i. \\
\hline Po-1 & 2402.5 & U. K. & 0.55 & 0.70 & 0.67 & 0.56 & 0.16 & 0.05 & 0.08 & 0.03 & 1.3 & 1.23 \\
\hline Pr-1 & 1992.5 & U. K. & 0.55 & 0.70 & 0.58 & 0.54 & 0.19 & 0.09 & 0.10 & 0.11 & 1.0 & 1.27 \\
\hline St-1 & 1590.5 & U. K. & 0.36 & 0.58 & 0.75 & 0.58 & 0.05 & 0.06 & 0.11 & 0.03 & 2.0 & 1.49 \\
\hline Ko-3 & 2218.6 & L. K. & 0.46 & 0.65 & 1.05 & 0.62 & 0.06 & 0.09 & 0.16 & 0.03 & 1.7 & 1.22 \\
\hline \multicolumn{13}{|c|}{ Mid-Polish Anticlinorium } \\
\hline $\mathrm{Ci}-2$ & 561.7 & U. K. & 0.70 & 0.79 & 0.76 & 0.58 & 0.04 & 0.11 & 0.17 & 0.10 & 1.1 & 1.56 \\
\hline Cy-1 & 1089.3 & U. K. & 0.62 & 0.74 & 0.61 & 0.55 & 0.13 & 0.05 & 0.10 & 0.02 & 2.0 & 1.77 \\
\hline Go-7 & 1177.2 & U. K. & 0.72 & 0.80 & 1.44 & 0.67 & 0.04 & 0.04 & 0.07 & 0.03 & 2.9 & 1.59 \\
\hline \multicolumn{13}{|c|}{ Kościerzyna-Puławy Synclinorium } \\
\hline Gr-1 & 1651.4 & U. K. & 0.31 & 0.56 & 0.69 & 0.57 & 0.12 & 0.07 & 0.10 & 0.06 & 1.3 & 1.47 \\
\hline
\end{tabular}

MPI1 = 1.5(2MP + 3MP $) /($ Phen + 1MP + 9MP $) ; M P-$ Methylphenanthrene; Phen - Phenanthrene; $R_{\text {cal }(\mathrm{MPI} 1)}=0.6(\mathrm{MPI} 1)+0.37$ $\mathrm{MDR}=4 \mathrm{MDBT} / 1 \mathrm{MDBT} ; \mathrm{MDBT}-$ Methyldibenzothiophene; $\mathrm{R}_{\mathrm{cal}(\mathrm{MDR})}=0.4+0.3^{*}(\mathrm{MDR})-0.094^{*}(\mathrm{MDR})^{2}+0.0118(\mathrm{MDR})^{3} ; \mathrm{DBT}-$ dibenzothiophene; $\mathrm{TA}(\mathrm{I})=\left(\mathrm{C}_{20}+\mathrm{C}_{21}\right)$ Triaromatic Steroids; $\mathrm{TA}(\mathrm{II})=\left(\mathrm{C}_{26}+\mathrm{C}_{27}+\mathrm{C}_{28}+\mathrm{C}_{29}\right)$ Triaromatic Steroids; TA 20/(20+27)= $\mathrm{C}_{20}$ Triaromatic Steroid/ $\left(\mathrm{C}_{20}+\mathrm{C}_{27} 20 \mathrm{~S} \& \mathrm{C}_{26} 20 \mathrm{R}+\mathrm{C}_{27} 20 \mathrm{R}\right)$ Triaromatic Steroids; TA 21/(21+28) $=\mathrm{C}_{21}$ Triaromatic Steroid/ $\left(\mathrm{C}_{21}\right.$ $+\mathrm{C}_{28} 20 \mathrm{~S}+\mathrm{C}_{28}$ 20R) Triaromatic Steroids; TA $\mathrm{C}_{28} / \mathrm{C}_{26} 20 \mathrm{~S}=\mathrm{C}_{28} 20 \mathrm{~S}$ Triaromatic Steroid $/ \mathrm{C}_{26} 20 \mathrm{~S}$ Triaromatic Steroid; TA $\mathrm{C}_{28} /$ $\mathrm{C}_{27} 20 \mathrm{R}=\mathrm{C}_{28} 20 \mathrm{R}$ Triaromatic Steroid $/ \mathrm{C}_{27} 20 \mathrm{R}$ Triaromatic Steroid; I.i. - not calculated due to low intensity of biomarkers; other explanationa as in Figure 2
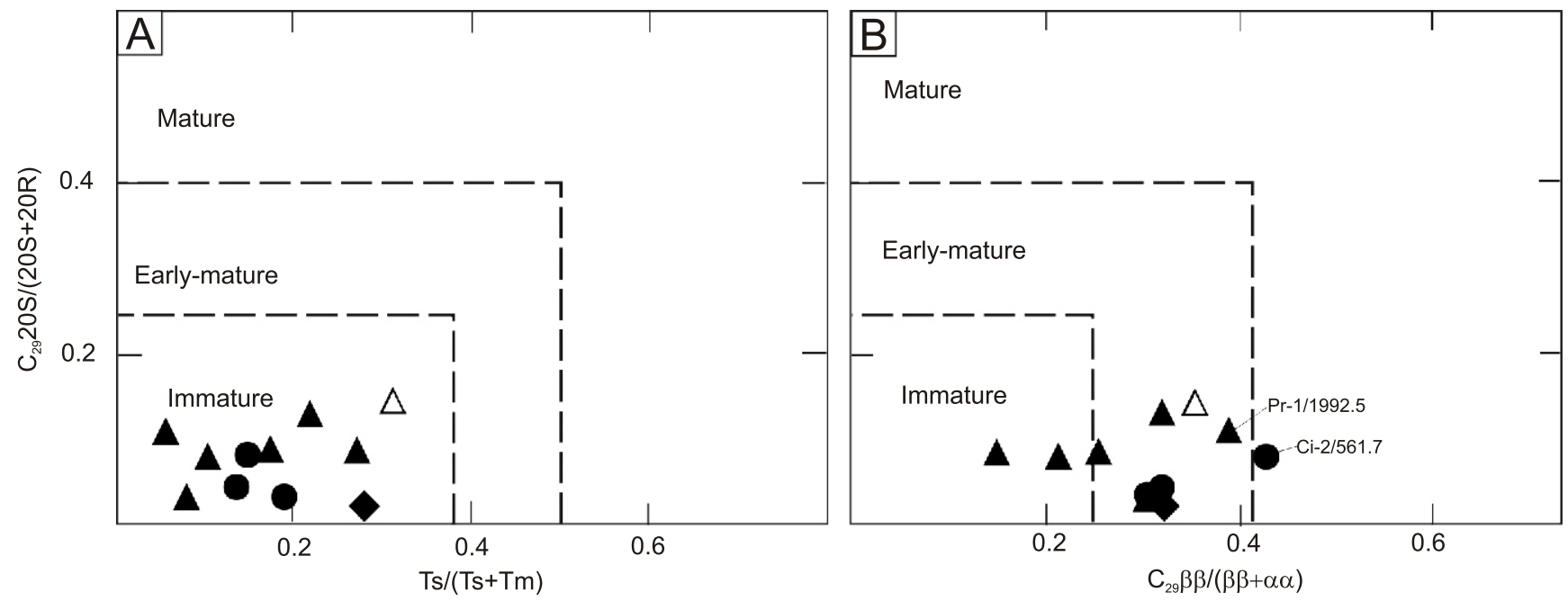

Fig. 17. Sterane $C_{29} 20 S /(20 S+20 R)$ ratio versus $(A) T s /(T s+T m)$ and $(B) C_{29} \beta \beta /(\beta \beta+\alpha \alpha)$ ratios for bitumen

Maturity fields after Peters and Moldowan (1993); explanationa as in Figure 2

samples were collected from 6 boreholes, and from Upper Kimmeridgian - 59 samples from 9 boreholes (Table 1). The TOC content varies in the Lower Kimmeridgian strata from 0.18 to 6.8 wt.\%, with the median of 0.94 , and in the Upper Kimmeridgian - from 0.25 to 6.6 wt.\% (median 2.6 wt.\%; Table 2). The TOC distribution, both in Lower and Upper Kimmeridgian rocks, is uniform with statistical dominance of higher values in Upper Kimmeridgian strata (Fig. 2B). The highest TOC values, $>5$ wt. $\%$, were recorded in Upper Kimmeridgian strata of the Gostynin IG 1, IG 3, 7 and Ciechocinek IG 2 boreholes, and in a single Lower Kimmeridgian sample from Gostynin IG 3 (Fig. 1). The values of residual hydrocarbon content $\left(S_{2}\right)$ and total hydrocarbon content $\left(S_{1}+S_{2}\right)$ vary in Lower Kimmeridgian strata $S_{1}+S_{2}$ from 0.09 to $25.4 \mathrm{mg} \mathrm{HC} / \mathrm{g}$ rock (Table 2 and Fig. 2B), and in Upper Kimmeridgian - from 0.34 to $26.1 \mathrm{mg} \mathrm{HC} / \mathrm{g}$ rock, respectively, with the median values of 1.05 and $4.2 \mathrm{mg} \mathrm{HC} / \mathrm{g}$ rock, respectively (Table 2 and Fig. 2B). These data indicate that the Lower Kimmeridgian strata are generally fair source rocks and the upper part of the Kimmeridgian section is potentially good source for the generation of hydrocarbons. The highest medians of TOC value in individual boreholes are evidenced in the vicinity of Gostynin (Fig. 1). 
In the Kimmeridgian strata of this tectonic unit, as in the case of the Szczecin-Miechów Synclinorium, different types of kerogen are recognized. The correlation between the hydrogen index $\mathrm{HI}$ and the $T_{\max }$ temperature (Fig. 3B) indicates the predominance of gas-prone Type-III kerogen in the whole Kimmeridgian section with numerous levels containing mixed Type-II/III and locally Type-II kerogen, mostly in the Upper Kimmeridgian strata. The highest $H I$ values were recorded in the Gostynin IG 1 and Czarnowo-2 boreholes. The "mineral matrix effect" is difficult to recognize; the low-HI-value-samples are both rich and poor in organic carbon, both in the Lower and Upper Kimmeridgian (Fig. 4B). The lowering of TOC content results in the increase of $\mathrm{Ol}$ values (especially in the Lower Kimmeridgian) suggesting partial oxidation of organic matter in TOC-poor rocks (Fig. 4B'). The results of petrographic analyses (Table 3 and Fig. 5) and the stable carbon isotope composition (Table 4, Figs. 6B and 7) of selected samples indicate the dominance of oil-prone Type-II kerogen. Stable carbon isotope analyses show a narrow range of $\delta^{13} \mathrm{C}$ values of kerogen and all fractions, suggesting the presence of one type of organic matter and some differences between $\delta^{13} \mathrm{C}$ values of aromates in the whole section. In samples collected from Lower Kimmeridgian strata, aromatics are more enriched in the ${ }^{12} \mathrm{C}$ isotope as compared to saturates (Figs. 6B and 7), suggesting secondary processes (oxidation, water washing), as reported by, e.g., Kotarba et al. (2006) for the Permian Kupferschiefer. This thesis is confirmed by lowering of the $\mathrm{HIIO}$ ratio in these samples (Fig. 8). The oxidation of organic matter in the investigated strata is possible due to the presence of geothermal waters of low salinity (Górecki, 2006). The kerogen elemental composition, in contrast to previous data, suggests a predominance of Type-III kerogen (Table 5 and Fig. 9), but as for the samples from the Szczecin-Miechów Synclinorium, the maceral composition of these samples is dominated by liptinite and inertinite macerals (Table 3 and Fig. 5). Therefore, the kerogen elemental composition refers to the composition of a mixture of algal material (Type-II or Type-I kerogen) and inert organic matter (Type-IV) kerogen. The presence of low-sulphur kerogen is evidenced by the low values of S/C atomic ratios in kerogen, below 0.04 (Table 5) in the Upper Kimmeridgian strata. The positive correlation of S/C and $\mathrm{H} / \mathrm{C}$ atomic ratios (Fig. 10) may indicate, as with the previously described samples from the Szczecin-Miechów Synclinorium, a mixture of high-sulphur kerogen (Type-IIS) and low-sulphur kerogen (most probably Type-IV). Indices calculated based on the $n$-alkanes and isoprenoids distribution (Table 6) and the biomarker distribution (Table 7) support the petrographic analyses and suggest generation of the bitumen from organic matter enriched in algae (Fig. 13). It is impossible to determine the conditions of organic matter deposition based on the Pristane/Phytane ratio due to the very low quantities of these biomarkers in bitumen. Low values of the gammacerane index $(G /)$ indicate the absence of hypersaline sedimentation environment (Sininghe Damste et al., 1995). The values of ratios calculated on the basis of the distribution of $n$-alkanes, steranes, diasteranes and hopanes (Tables 6 and 7) indicates a diversity of organic matter deposition conditions. The CPI values $>1.0$ reveal that the organic matter was deposited most probably in rocks enriched in siliclastic material. On the other hand, the value of $\mathrm{C}_{26} / \mathrm{C}_{25}$ of triterpanes ratio of sample Ci-2/561.7 above unity (Table 7 and Fig. 15) suggests the presence of lacustrine Type-I kerogen (e.g., Zumberge, 1987), but this thesis has not been supported by the results of other analyses (Tables 3-7). Especially low values of the $\mathrm{HI}$ and $\mathrm{H} / \mathrm{C}$ atomic ratio (Tables 4 and 5, Fig. 8) prove the predominance of Type-Il kerogen.
Thermal maturity of the Kimmeridgian strata was determined, as in the case of the Szczecin-Miechów Synclinorium, on the basis of Rock-Eval data (Table 2), vitrinite reflectance measurements (Table 3), and biomarker (Table 7) and aromatic hydrocarbons distribution (Table 8). The results of the kerogen elemental composition analysis $(\mathrm{H} / \mathrm{C}$ and $\mathrm{O} / \mathrm{C}$ values $)$ were also used indirectly for this purpose (Table 5). The $T_{\max }$ values from 418 to $435^{\circ} \mathrm{C}$ (Table 2 and Fig. 3B) indicate generally the immaturity and low-maturity of the investigated strata. The maturity indices calculated based on the distribution of biomarkers, methylphenantrenes, methyldibenzotiophenes and triaromatic steroids (Tables 7 and 8, Figs. 16 and 17), elemental composition of kerogen (Fig. 9), as well as vitrinite reflectance (Table 3 ) generally correspond with $T_{\max }$ values and indicate a lower level of thermal maturity in this unit than in the Szczecin-Miechów Synclinorium. These data are in agreement with previous studies (e.g., Burzewski et al., 1990; Nowicki, 1990; Bachleda-Curuś and Semyrka, 1990; Merta, 1994).

KOŚCIERZYNA-PUŁAWY SYNCLINORIUM

From the Kościerzyna-Puławy Synclinorium, 24 samples were collected from 5 boreholes (Table 1 and Fig. 1). Six samples came from 2 boreholes in the Kościerzyna Segment, and 18 samples originated from 3 boreholes in the Warszawa Segment. In the Lower Kimmeridgian strata (6 samples -2 from Kościerzyna and 4 from Warszawa segments) the TOC content varies from 0.22 to $3.2 \mathrm{wt} . \%$, with the median of $0.40 \mathrm{wt} . \%$ (Table 2). Samples with low TOC values are dominant, but there is one sample from the Gostynin IG 4 borehole with a high organic carbon content of $>3 \mathrm{wt}$.\% (Figs. 1 and $2 \mathrm{C}$ ). The residual hydrocarbon content $\left(S_{2}\right)$ as well as total hydrocarbon content $\left(S_{1}+S_{2}\right)$, similarly to the TOC values, are usually low and range from 0.19 to $11.6 \mathrm{mg} \mathrm{HC} / \mathrm{g}$ rock and 0.26 to $11.9 \mathrm{mg} \mathrm{HC} / \mathrm{g}$ rock, respectively, with the median values of 0.29 and $0.38 \mathrm{mg} \mathrm{HC} / \mathrm{g}$ rock, respectively (Table 2 and Fig. $2 \mathrm{C}$ ), indicating that the the strata generally have poor potential for the generation of hydrocarbons. The $S_{2}+S_{1}$ value exceeds $5 \mathrm{mg} \mathrm{HC} / \mathrm{g}$ rock only in one sample (Gostynin IG 4/1678.3 m; Fig. 2C). The Upper Kimmerigdian strata are much richer in organic matter: the TOC varies from 0.38 to $5.6 \mathrm{wt} . \%$ (median $2.4 \mathrm{wt} . \%$ ), and the hydrocarbon content is from 0.26 to $26.7 \mathrm{mg} \mathrm{HC} / \mathrm{g}$ rock (median 4.3 $\mathrm{mg} \mathrm{HC} / \mathrm{g}$ rock; Table 2 and Fig. 2C). The best source rocks were found in the Gronowo-1 and Gostynin IG 4 boreholes (Figs. 1 and 2C).

Kimmeridgian strata of this tectonic unit, like with the previous ones, contain different types of kerogen. Correlation between the hydrogen index $(H I)$ and the $T_{\max }$ temperature (Fig. 3C) indicates the dominance of gas-prone Type-III kerogen in Lower Kimmeridgian strata, while in the upper part of the section, numerous levels contain mixed Type-II/III and Type-II kerogen (Gronowo-1 borehole). This thesis is supported by the correlation of $\mathrm{HI}$ and TOC (Fig. 4C). The "mineral matrix effect" is visible for samples poor in TOC. The oxidation of organic matter was recorded especially in samples collected from the Lower Kimmeridgian strata (Fig. 4C'). The results of petrographic analyses (Table 3 and Fig. 5), stable carbon isotope composition (Table 4, Figs. 6B, 7 and 8), kerogen elemental composition (Table 5, Figs. 9 and 10), Pristane $/ n-\mathrm{C}_{17}$ and Phytane/ $n-\mathrm{C}_{18}$ ratios values (Table 6 and Fig. 12) and regular sterane distribution (Table 7 and Fig. 13) of one sample (Gronowo-1/1651.5 m) indicate that its organic geochemistry characteristics is similar to those of the samples from the Mid-Polish Anticlinorium. The value of $\mathrm{Pr} / \mathrm{Ph}$ ratio below one 
(Table 6) suggests a deposition of the organic material in anoxic conditions (Didyk et al., 1978). Hypersaline sedimentation environment was excluded due to the absence of gammacerane (Table 7). Values of the Pristane/Phytane and Phenanthrene/Dibenzothiophene ratios suggest the generation of bitumen from organic matter deposited in lacustrine or organic-poor carbonaceous conditions (Fig. 14). This opinion is misleading taking into consideration deep marine conditions during Kimmeridgian times (Niemczycka nad Brochwicz-Lewiński, 1988). The palaeoecological data are supported by the value of $\mathrm{C}_{26} / \mathrm{C}_{25}$ of triterpanes ratio of less than unity (Table 7 and Fig. 15), suggesting a dominance of Type-II kerogen deposited in marine shales. The low value of the $\mathrm{S} / \mathrm{C}$ atomic ratio in kerogen (Table 5 and Fig. 10) reveals the presence of low-sulphur (low-generative) kerogen (Orr, 1986), however, as for the previous units, a mixture of Type-IIS kerogen with inert Type-IV kerogen cannot be excluded here, either.

Thermal maturity of the Kimmeridgian strata in the Kościerzyna-Puławy Synclinorium was determined, as in the case of previous units, on the basis of Rock-Eval data (Table 2), measurements of vitrinite reflectance (Table 3 ), and biomarker (Table 7) and aromatic hydrocarbons distribution (Table 8). The results of the kerogen elemental composition analysis $(\mathrm{H} / \mathrm{C}$ and $\mathrm{O} / \mathrm{C}$ values) were also used indirectly for this purpose (Table 5 ). The $T_{\max }$ values from 412 to $432^{\circ} \mathrm{C}$ (Table 2 and Fig. $3 \mathrm{C}$ ) indicate generally the immaturity and only locally marginal low-maturity of the investigated strata. The maturity indices calculated based on the distribution of biomarkers, methylphenantrenes, methyldibenzotiophenes and triaromatic steroids (Tables 7 and 8, Figs. 16 and 17), elemental composition of kerogen (Fig. 9), as well as vitrinite reflectance (Table 3 ) generally correspond with the $T_{\max }$ values and indicate a lower level of thermal maturity in this unit than in the Szczecin-Miechów Synclinorium. These data are in agreement with previous studies (e.g., Burzewski et al., 1990; Nowicki, 1990; Bachleda-Curuś and Semyrka, 1990; Merta, 1994).

\section{CONCLUSIONS}

The wide range of geochemical studies enabled to evaluate detailed hydrocarbon potential, genetic type, and maturity of potential source rocks in the Upper and Lower Kimmeridgian strata of the central part of the Polish Lowland:

1. The rocks richest in TOC, up to $6.8 \mathrm{wt} . \%$, were found in the Gostynin-7 (Upper Kimmeridgian) and Gostynin IG 3 (Lower Kimmeridgian) boreholes in the eastern part of the Mid-Polish Anticlinorium (Kuiavian Segment). Source rock lev- els with TOC $>4$ wt. $\%$ were also found in the Upper Kimmeridgian in all investigated units. Lower Kimmeridgian rocks are generally poor in organic matter.

2. Hydrocarbon potential of the rocks is varied: generally poor for the Lower Kimmeridgian and fair or good for Upper Kimmeridgian strata. The source-rock properties are comparable in all the units.

3. The Lower Kimmeridgian rocks contain predominantly gas-prone Type-III kerogen. Oil-prone type-II kerogen prevails in the Upper Kimmeridgian strata.

4. Highly generative Type-IIS kerogen has not been recorded in the analysed strata, thus organic sulphur does not play any important role in the hydrocarbon generation. In comparison to other parts of the basin, where kerogen II-S is widespread, its presence in the study area cannot be excluded.

5. Organic matter is immature or low-mature in all analysed rocks. The highest maturities are observed in the most deeply buried strata $(>2000 \mathrm{~m})$ in the Mogilno-Łódź Segment of the Szczecin-Miechów Synclinorium. In the Mid-Polish Anticlinorium and Kościerzyna-Puławy Synclinorium, the maturity is lower, indicating that hydrocarbon generation processes have not started in this area.

6. Taking into consideration the high TOC content in some areas, the Kimmeridgian strata may be an interesting target for exploration of unconventional microbial hydrocarbons, especially in the deepest parts of the Mogilno-Łódź Segment of the Szczecin-Miechów Synclinorium (Damasławek-Strzelno-Koło area), where also the thermogenic generation process began and Upper Jurassic rocks are covered by thick Cretaceous strata.

Acknowledgements. The investigations were financed by the Ministry of Science and Higher Education (Projects nos. N307 314139 and 744/N-IRAN/2010/0) and carried out at the AGH University of Science and Technology in Kraków. F. Czechowski from the University of Wrockaw, A. FeldmanOlszewska from the Polish Geological Institute - National Research Institute in Warsaw, J.V. Koltun from Ukrainian Academy of Sciences in Lviv, and Chief Editor T.M. Peryt from the Polish Geological Institute - National Research Institute in Warsaw provided very constructive reviews, which greatly improved the discussion and working hypotheses presented in the manuscript. Analytical work by A. Kowalski, T. Kowalski and H. Zych from the AGH University of Science and Technology in Kraków is gratefully acknowledged. The author thanks I. Grotek from the Polish Geological Institute - National Research Institute in Warsaw for vitrinite reflectance measurements and determination of maceral composition of organic matter.

\section{REFERENCES}

Bachleda-Curuś, T., Semyrka, R., 1990. The hydrocarbon balance for the Mesozoic sedimentary complex in the central part of the Polish Lowland (in Polish with English summary). Zeszyty Naukowe AGH, Geologia, 49.

Bachleda-Curuś, T., Burzewski, W., Semyrka, R., 1992. The regional synthesis of the petroleum generation in the Mesozoic strata of the Polish Lowlands. Bulletin of the Polish Academy of Sciences, Earth Sciences, 40: 251-265.

Berner, R.A., 1990. Atmospheric carbon dioxide levels over Phanerozoic time. Science, 249: 1382-1386.
Burzewski, W., Bachleda-Curuś, T., Semyrka, R., 1990. Potencjał węglowodorowy synklinorium mogileńsko-łódzkiego $\mathrm{w}$ strefie Przybyłowa (in Polish). Nafta, 46: 1-8.

Coplen, T.B., 2011. Guidelines and recommended terms for expression of stable-isotope-ratio and gas-ratio measurement results. Rapid Communications in Mass Spectrometry, 25: 2538-2560.

Cornford, C., 1994. Mandal-Ekofisk (!) Petroleum System in the Central Graben of the North Sea. AAPG Memoir, 60: 537-571.

Curtis, J.B., Kotarba, M.J., Lewan, M.D., Więcław, D., 2004. Oil/source rock correlations in the Polish Flysch Carpathians and Mesozoic basement and organic facies of the Oligocene 
Menilite Shales: insights from hydrous pyrolysis experiments Organic Geochemistry, 35: 1573-1596.

Dadlez, R., Marek, S., 1997. Rozwój basenów permu i mezozoiku (in Polish). Prace Państwowego Instytutu Geologicznego, 153: 403-409.

Dembowska, J., 1979. Systematization of lithostratigraphy of the Upper Jurassic in northern and central Poland (in Polish with English summary). Kwartalnik Geologiczny, 23 (3): 617-630.

Dessort, D., Connan, J., Derenne, S., Largeau, C., 1997. Comparative studies of the kinetic parameters of various algaenans and kerogens via open-system pyrolyses. Organic Geochemistry, 26: 705-720.

Didyk, B.M., Simoneit, B.R.T., Brassel, S.C., Eglinton, G., 1978 Organic geochemical indicators of palaeoenvironmental conditions of sedimentation. Nature, 272: 216-222.

Espitalié, J., Deroo, G., Merquis, F., 1985. La pyrolyse Rock Eval et ses applications. Revue Institut Français du Pétrole, 40 755-784.

Espitalié, J., Lafargue, E., Eggen, S., 1991. Petroleum potential of terrestrial and marine organic matter in Jurassic sequences of the northern North Sea and offshore mid-Norway. EAPG Special Publication, 1: 49-63.

Gautier, D.L., 2005. Kimmeridgian shales total petroleum system of the North Sea Graben Province. U.S. Geological Survey Bulletin, 2204-C

Geluk, M.C., 2007. Permian. In: Geology of the Netherlands (eds. Th.E. Wong, D.A.J. Blatjes and J. de Jager): 63-83. Royal Netherlands Academy of Arts and Sciences.

Górecki, W., ed., 2006. Atlas of geothermal resources of Mesozoic formations in the Polish Lowlands (in Polish with English summary). Ministry of the Environment, the National Fund for Environmental Protection and Water Management, AGH - University of Science and Technology, Polish Geological Institute.

Grotek, I., 2012. Charakterystyka petrologiczna oraz dojrzałość termiczna materii organicznej rozproszonej w utworach mezozoiku (in Polish). Profile Głębokich Otworów Wiertniczych Państwowego Instytutu Geologicznego, 133: 132-136.

Hallam, A., 1985. A review of Mesozoic climates. Journal of the Geological Society, 142: 433-445.

Hughes, W.B., Holba, A.G., Dzou, L.I.P., 1995. The ratios of dibezothiophene to phenantrene and pristane to phytane as indicators of depositional environment and lithology of petroleum source rocks. Geochimica et Cosmochimica Acta, 59: $3581-3598$

Hunt, J.M., 1996. Petroleum Geochemistry and Geology. W.H. Freeman and Company, New York.

Justwan, H., Dahl, B., 2005. Quantitative hydrocarbon potential mapping and organofacies study in the Greater Balder Area, Norwegian North Sea. In: Petroleum Geology: North-West Europe and Global Perspectives (eds. A.G. Dore and B.A. Vining) 1317-1329. Proceedings of the 6th Petroleum Geology Conference.

Karnkowski, P., 1999. Oil and Gas Deposits in Poland. The Geosynoptics Society "Geos" and University of Mining and Metallurgy, Cracow.

Karnkowski, P.H., 2008. Tectonic subdivision of Poland: Polish Lowlands (in Polish with English summary). Przegląd Geologiczny, 56: 895-903.

Klimuszko, E., 2012. Charakterystyka geochemiczna materii organicznej (in Polish). Profile Głębokich Otworów Wiertniczych Państwowego Instytutu Geologicznego, 133: 137-144.

Köster, J., Rospondek, M., Schouten, S., Kotarba, M., Zubrzycki, A., Sinninghe Damsté, J.S., 1998. Biomarker geochemistry of a foredeep basin: the Oligocene Menilite Formation in SE Poland. Organic Geochemistry, 29: 649-669.

Kosakowski, P., Więcław, D., Kotarba, M.J., Kowalski, A., 2012. Habitat and hydrocarbon potential of the Mesozoic strata in the Kraków-Rzeszów area (SE Poland). Geological Quarterly, 56 (1): 139-152.
Kotarba, M.J., Peryt, T.M., Kosakowski, P., Więcław, D., 2006. Organic geochemistry, depositional history and hydrocarbon generation modelling of the Upper Permian Kupferschiefer and Zechstein Limestone strata in south-west Poland. Marine and Petroleum Geology, 23: 371-386.

Kotarba, M.J., Wieclaw, D., Koltun, Y.V., Marynowski, L., Kuśmierek, J., Dudok, I.V., 2007. Organic geochemical study and genetic correlation of natural gas, oil and Menilite source rocks in the area between San and Stryi rivers (Polish and Ukrainian Carpathians). Organic Geochemistry, 38: 1431-1456.

Krzywiec, P., 2006. Structural inversion of the Pomeranian and Kuiavian segments of the Mid-Polish Trough - lateral variations in timing and structural style. Geological Quarterly, 50 (1): 151-168.

Leenheer, M.J., 1984. Mississippian Bakken and equivalent formations as source rocks in the western Canadian basins. Organic Geochemistry, 6 (C): 521-532.

Lewan, M.D., 1998. Sulphur-radical control on petroleum formation rates. Nature, 391: 164-166.

Magri, F., Littke, R., Rodon, S., Bayer, U., Urai, J.L., 2008. Temperature fields, petroleum maturation and fluid flow in the vicinity of salt domes. In: Dynamics of Complex Intracontinental Basins: The Central European Basin System (eds. R. Littke, U. Bayer, D. Gajewski and S. Nelskamp): 323-344. Springer, Berlin.

Merta, H., 1994. Możliwości generowania weglowodorów z utworów kimerydu i portlandu w strefie Damasławek-Mszczonów (in Polish). In: Badania geochemiczne i petrofizyczne w poszukiwaniach ropy naftowej i gazu ziemnego: 153-158. Balice, 27-28.06.1994.

Narkiewicz, M., Dadlez, R., 2008. Geological regional subdivision of Poland: general guidelines and proposed schemes of sub-Cenozoic and sub-Permian units (in Polish with English summary). Przegląd Geologiczny, 56: 391-397.

Niemczycka, T., 1983. Kimmeridgian and Volgian sediments in area of the Lipno Anticline (in Polish with English summary). Kwartalnik Geologiczny, 27 (2): 275-286.

Niemczycka, T., Brochowicz-Lewiński, W., 1988. Evolution of the Upper Jurassic sedimentary basin in the Polish Lowland (in Polish with English summary). Kwartalnik Geologiczny, 32 (1): 137-156.

Niemczycka, T., Radlicz, K., 1997. Jura górna, litostratygrafia i litofacje (in Polish). Prace Państwowego Instytutu Geologicznego, 153: 309-332.

Niemczycka, T., Malinowska, L., Styk, O., Sztejn, J., Gaździcka, E., 1997. Jura górna, biostratygrafia (in Polish). Prace Państwowego Instytutu Geologicznego, 153: 283-309.

Nowicki, M., 1990. Ilościowa ocean zasobów prognostycznych ropy naftowej i gazu ziemnego w kompleksach strukturalnych: triasowo-jurajskim i kredowym Polski (in Polish). Technika Poszukiwań Geologicznych Geosynoptyka i Geotermia, 29: 47-50.

Obermajer, M., Fowler, M.G., Snowdon, L.R., 1999. Depositional environment and oil generation in Ordovician source rocks from southwestern Ontario, Canada: organic geochemical and petrological approach. AAPG Bulletin, 83: 1426-1453.

Orr, W.L., 1986. Kerogen/asphaltene/sulfur relationships in sulfur-rich Monterey oils. Organic Geochemistry, 10: 499-516.

Peters, K.E., Cassa, M.R., 1994. Applied source rock geochemistry. AAPG Memoir, 60: 93-102.

Peters, K.E., Moldowan, J.M., 1993. The Biomarker Guide: Interpreting Molecular Fossils in Petroleum and Ancient Sediments. Englewood Cliffs, Prentice-Hall, New Jersey.

Peters, K.E., Walters, C.C., Moldowan, J.M., 2005. The Biomarker Guide. Biomarkers and Isotopes in Petroleum Exploration and Earth History. Ed. 2. University Press, Cambridge.

Philp, R.P., 1985. Fossil Fuel Biomarkers. Applications and Spectra. Elsevier, Amsterdam 
Riding, R., 2001. Calcified algae and bacteria. In: The Ecology of the Cambrian Radiation (eds. A.Yu. Zhuravlev and R. Riding): 445-473. Columbia University Press, New York.

Sinninghe Damste, J.S., Kenig, F., Koopmans, M.P., Köster, J., Schouten, S., Hayes, J.M., de Leeuw, J.W., 1995. Evidence for gammacerane as an indicator of water column stratification. Geochimica et Cosmochimica Acta, 59: 1895-1900.

Sofer, Z., 1984. Stable carbon isotope compositions of crude oils: application to source depositional environments and petroleum alteration. AAPG Bulletin, 68: 31-49.

Waples, D.W., 1980. Time and temperature in petroleum formation application of Lopatin's method to petroleum exploration. AAPG Bulletin, 64: 916--926.

Weedon G.P., Coe, A.L., Gallois, R.W., 2004. Cyclostratigraphy, orbital tuning and inferred productivity for the type Kimmeridge Clay (Late Jurassic), Southern England. Journal of the Geological Society, 161: 655-666.

Wierzbowski, A., 1991. Biostratigraphical correlations around the Oxfordian/Kimmeridgian boundary. Acta Geologica Polonica, 41: 149-155.

Wierzbowski, H., 2004. Carbon and oxygen isotope composition of Oxfordian-Early Kimmeridgian belemnite rostra: palaeoenvironmental implications for Late Jurassic seas.
Palaeogeography, Palaeoclimatology, Palaeoecology, 203: 153--168.

Więcław, D., 2011. Origin of liquid hydrocarbons in the Miocene strata of the Polish Carpathian Foredeep and its Palaeozoic Mesozoic basement. Annales Societatis Geologorum Poloniae, 81: 443-458.

Więcław, D., Kotarba, M.J., Kowalski, A., Kosakowski, P., 2011. Habitat and hydrocarbon potential of the Palaeozoic source rocks in the Kraków-Rzeszów area (SE Poland). Annales Societatis Geologorum Poloniae, 81: 375-394.

Więcław, D., Kotarba M.J., Kowalski, A., Koltun Y.V., 2012. Origin and maturity of oils in the Ukrainian Carpathians and their Mesozoic basement. Geological Quarterly, 56 (1): 153-168.

Wilczek, T., Merta, H., 1992. The preliminary results of pyrolytic investigations by Rock-Eval method (in Polish with English summary). Nafta, 48: 109-116.

Zumberge, J.E., 1987. Prediction of source rock characteristics based on terpane biomarkers in crude oils: A multivariate statistical approach. Geochimica et Cosmochimica Acta, 51: 1625-1637.

Żelaźniewicz, A. Aleksandrowski, P., Buła, Z., Karnkowski, P.H., Konon, A., Oszczypko, N., Ślęczka, A., Żaba, J., Żytko, K., 2011. Regionalizacja tektoniczna Polski (in Polish). Komitet Nauk Geologicznych PAN, Wrocław. 